\title{
Stereotyping Women, Individualizing Harassment: The Dignitary Paradigm of Sexual Harassment Law Between the Limits of Law and the Limits of Feminism
}

\author{
Noya Rimalt ${ }^{\dagger}$
}

INTRODUCTION 392

I. The ORIGIN AND SubstancE OF THE DignitaRy CHALlENGE TO

SEXUAl HaRASSMENT LaW: A COMPARATIVE PERSPECTIVE 395

II. ISRAEL'S PREVENTION OF SEXUAL HARASSMENT LAW-A NEW

APPROACH TO AN OLD PROBLEM ................................................. 401

A. General Background .............................................................. 401

B. Relevant Features and Underlying Rationales ............................. 404

C. The Dignitary Paradigm of the Prevention of Sexual

Harassment Law-Normative Ambiguity and Gendered

Implications

III. SeXUal Harassment CASELAW-FaCTS AND ANALYSIS ...................412

A. The Supreme Court of Israel......................................................414

1. Four Conceptual Frames of Reference in Ben-Asher and Galili

2. Subsequent Supreme Court Cases Further Establish and

Develop the Four Frames of Reference.

3. Recent Developments in Supreme Court Caselaw

B. Sexual Harassment Caselaw in Lower Courts

IV. SeXual HaRASSMENT LAW: BETWEEN THE Limits of LAW AND THE

LIMITS OF FEMINISM 442

CONCLUSION 446

\footnotetext{
$\dagger$ Associate Professor of Law, Faculty of Law, University of Haifa. I have benefited from thoughtful comments on previous drafts from Ronit Haramti-Alpern and from my students in the Law and Feminism class. My grateful thanks to Tali Eisenberg for her excellent research assistance and to Hadas Agmon for providing tremendous help in preparing the piece for publication.
}

Copyright $\odot 2008$ by the Yale Journal of Law and Feminism 


\section{INTRODUCTION}

This Article explores the manner in which Israeli courts "talk" about sexual harassment and conceptualize its harm. Based on a thorough analysis of contemporary sexual harassment caselaw in Israel, it presents the first systematic study of all reported court opinions on sexual harassment that have been issued following the enactment of the Prevention of Sexual Harassment Law in 1998.

From a global perspective, Israeli sexual harassment law provides both an intriguing example of an effort to use the law as a tool for social change and a realization of contemporary doctrinal and normative challenges to sexual harassment law in the United States and in Europe. The recent sexual harassment legislation in Israel was inspired and promoted by feminist activists and academics, whose cooperation with members of the Knesset (the Israeli Parliament) and with attorneys at the Ministry of Justice facilitated the successful enactment of the law in 1998. In this regard, this law and its subsequent interpretation and application present an important example of feminist lawmaking in action and of its actual impact on women's lives. In addition, feminist proponents of the Israeli legislation aspired to offer a new conceptualization of sexual harassment, in comparison to the American example. Their goal was to carefully examine U.S. sexual harassment law, to identify its drawbacks, and to devise a new and better formulation for the Israeli context in light of the unique features of Israeli society and law. One major implication of this feminist effort to improve the traditional legal framework of sexual harassment law was the reconceptualization of this social phenomenon primarily as a dignitary harm. Instead of associating sexual harassment exclusively with sex-based discrimination, as is prevalent in the United States, the new Israeli law proclaims that sexual harassment violates, first and foremost, human dignity. Along with liberty and privacy, the law refers to equality between the sexes as an alternative rather than exclusive social value that is relevant to understanding the underlying wrongs inherent in sexual harassment. ${ }^{1}$

Taking into consideration those two aspects of the Prevention of Sexual Harassment Law in Israel, this Article explores the various consequences of the Law's dignitary paradigm in terms of its potential implications for women's image and status in society. More specifically, this Article examines whether Israeli law has fulfilled its promise to promote a more progressive discourse on sexual harassment, and what lessons can be learned from this contemporary

1. Section 1 provides: "The objective of this Law is to prohibit sexual harassment, in order to protect human dignity, liberty and privacy and in order to promote equality between the sexes." Prevention of Sexual Harassment Law, 1998, S.H. 166 § 1. [Editors' note: All translations from Hebrew are by the author unless otherwise noted.] 
feminist effort to correct some of the major drawbacks of American sexual harassment doctrine.

Part I of this Article traces the origins of the dignity-based challenge to sexual harassment law and explains the broader context in which the dignitary paradigm of the Israeli legislation can be understood and evaluated. In this Part I explain that European legislatures were the first to draw a conceptual link between dignity and sexual harassment in the late 1980s. Following the European example, and due to a growing dissatisfaction with the existing state of sexual harassment doctrine, a few American feminists introduced this idea into their writing on sexual harassment and provided a newly-elaborated theoretical defense of the reconceptualization of the harms of sexual harassment in terms of dignity and respect.

In the United States, this dignity-based challenge to sexual harassment law remained purely theoretical. Israeli feminists, on the other hand, succeeded in promoting legislation that explicitly referred to the violation of human dignity as the primary harm associated with sexual harassment. Thus, with the enactment of the Prevention of Sexual Harassment Law, an idea that some American scholars were discussing on the theoretical level became a legal reality in Israel.

Part II explores the legislative history of Israel's Prevention of Sexual Harassment Law. Here I outline the specific arguments that Israeli feminists raised in favor of a new conceptualization of sexual harassment, and underscore the manner in which those arguments eventually shaped the dignity-based aspects of the new legislation. Yet, while the feminist decision to place dignity as the central value that defines the harm of sexual harassment was well thought-out, in this Part I also highlight some of the normative complexities inherent to the term 'dignity' in Hebrew that were disregarded in the drafting process of the new legislation.

Part III provides a thorough analysis of Israeli caselaw since the enactment of the Prevention of Sexual Harassment Law, and outlines the manner in which courts refer to sexual harassment and explain its harms. Specifically, this Part identifies four problematic themes that arise out of the dignity-based paradigm of contemporary sexual harassment caselaw in Israel. First, in the analysis of sexual harassment and its harms, this caselaw prioritizes dignity over equality so much so that the discriminatory aspects of this social practice are no longer part of the legal discourse. Thus, despite the fact that the legislation formally mentions equality as an additional value that is potentially relevant for the analysis of sexual harassment, contemporary judicial discourse focuses exclusively on dignity and explains the harm of sexual harassment solely in dignitary terms. Second, in some cases, courts present the dignitary harm of sexual harassment in gender-neutral and individual terms even though the various cases bear an unmistakably gendered significance. In the vast majority 
of sexual harassment cases I examined the following conditions were present: The harasser was a man, the target was a woman (or several women in the same setting), ${ }^{2}$ and the harassment occurred in the broader context of unequal gendered power relations in the public sphere and the workplace. Nonetheless, courts discuss these gender-based incidents of sexual harassment in genderneutral and individual terms, using language that indicates that one person has violated another person's dignity. This discourse disguises the gendered nature of sexual harassment and its particular harm to women and portrays it in misleadingly neutral terms. Third, in another set of cases, courts divert the dignitary frame of analysis and engage in a gendered discussion of the harm of sexual harassment. These cases acknowledge the gendered and group aspects of the phenomenon, but do so in moralistic and patriarchal terms that reinforce stereotypes of women and Victorian conceptions of women's honor. As part of this line of analysis, courts associate sexual harassment with the violation of women's honor and refer to the need to protect women from crude sexual behavior as the main purpose of the law. An underlying assumption that emerges out of this discourse is that the very exposure of women to various sexual behaviors is the central wrong of sexual harassment. Women are then stereotyped as fragile, sexually pure, and in need of a special protection. Finally, in the majority of cases I examined the dignitary paradigm of sexual harassment is explicitly correlated with sexual behaviors. Courts focus on the "sexual" in sexual harassment, thereby legitimating other forms of sex-based harassment that working women often experience.

Part IV raises some possible explanations for these current features of sexual harassment caselaw in Israel and argues that they appear to be the product of three crucial choices that the legislation's drafters made. The first was the very decision to list gender equality as one of several values including human dignity, liberty, and privacy that were declared relevant for the analysis of sexual harassment. The second decision that immediately followed was to award a special and primary role within this complex assembly of values to dignity as the central normative frame of reference for the definition of the wrong of sexual harassment. The third choice was the decision to criminalize sexual harassment and within the criminal context to associate this social practice with other sex offenses, such as "indecent behavior."

My final conclusion is that the dignity-based paradigm of sexual harassment as implemented by Israel's new legislation has led to outcomes that

2. Out of a total of 222 reported court opinions that I identified and examined, only three involved men as targets of harassment. In two of those cases the victims of harassment were vulnerable or less powerful men who did not conform to stereotypical patterns of masculinity because of sexual identity or age. One case involved a gay complainant, SC (Jer) 2272/05 Malca v. Ovsfeld Co. [2005] Pador 05(23) 99, and the second involved the harassment of several minors, CrimA 6644/06 Kraus v. Israel [2006] Pador 06(20) 331. The third case concemed harassment of a male worker by a fellow co-worker but was very brief in details so it was impossible to determine if it had a broader gendered significance. CrimC (Jer) 4399/01 Israel v. Barashi [2003] (non-paginated). 
are contrary to the goals of those who fought for it. Despite the fact that the enactment of the Prevention of Sexual Harassment Law brought about a marked rise in the number of court opinions dealing with sexual harassment, the battle that Israeli courts currently wage against sexual harassment is typically based on causes that are distant from what feminist proponents of the new legislation had in mind. Instead of becoming an educational, consciousness-raising tool that marks a new era in the awareness of sexual harassment among the Israeli public, sexual harassment law has achieved quite the opposite; it has hindered the broader and more radical task that the feminist forces who initiated the new law envisioned. Hence, for feminists, as for all other advocates of the dignitary paradigm of sexual harassment, the Prevention of Sexual Harassment Law provides a cautionary tale of the difficulties inherent in efforts to use the law as a bridge between radical agendas and existing social norms.

\section{The Origin and Substance of the Dignitary Challenge to SeXual HARASSMENT LAW: A COMPARATIVE PERSPECTIVE}

Israel's Prevention of Sexual Harassment Law is not unique in its definition of the harm of sexual harassment in primarily dignitary terms. Formal legal references to sexual harassment as a dignitary harm originated in Europe as early as the $1980 \mathrm{~s} .^{3}$ While American courts embraced the notion that sexual harassment is a form of sex discrimination a few years earlier, ${ }^{4}$ and inspired the initial European reference to sexual harassment as a legal wrong, ${ }^{5}$ European sexual harassment law revolved around concepts of dignity early on. ${ }^{6}$

As Europe began to address sexual harassment on a community level, one of the first measures it adopted was the 1984 European Community Council Recommendation, which referred to sexual harassment as a major problem affecting the dignity and rights of women. ${ }^{7}$ A subsequent resolution in 1990 on the Protection of the Dignity of Women and Men at Work ${ }^{8}$ similarly placed a

3. Susanne Baer, Dignity or Equality? Responses to Workplace Harassment in European, German, and U.S. Law, in DiRections in SEXUAl HaRAsSment LAw 582 (Catherine A. MacKinnon \& Reva B. Siegel eds., 2003); Anita Bernstein, Law, Culture, and Harassment, 142 U. PA. L. REV. 1227, 1262-64 (1994).

4. The first appellate court decision holding that sexual harassment is a form of sex discrimination under Title VIl of the Civil Rights Act of 1964 was Barnes v. Costle, 561 F.2d 983 (D.C. Cir. 1977). The United States Supreme Court affirmed this notion almost a decade later in Meritor Savings Bank $v$. Vinson, 477 U.S. 57 (1986).

5. Bernstein, supra note 3, at 1234-39; Gabrielle S. Friedman \& James Q. Whitman, The European Transformation of Harassment Law: Discrimination Versus Dignity, 9 COLUM. J. EUR. L. 241, 245 (2003).

6. Friedman \& Whitman, supra note 5 , at 245.

7. See Council Recommendation No. $84 / 635$ of 13 Dec. 1984, 1984 O.J. (L 331) 34 (on the promotion of positive action for women).

8. Council Resolution of 29 May 1990, 1990 O.J. (C 157) 3, available at http://eurlex.europa.eu/en/index.htm (on the protection of the dignity of women and men at work). This second 
particular focus on the dignitary aspects of this social practice and led to an official recommendation by the Commission of the European Community that adopted the same frame of reference for sexual harassment a year later. ${ }^{9}$ In 2000, two directives of the European Community Council supplemented this emphasis on dignity with a formal definition of workplace harassment as discrimination. ${ }^{10}$ However, when these Community measures were implemented by specific legislation in various member states of the European Community, especially in continental Europe, many adopted only the dignitary paradigm of sexual harassment without including or attributing similar weight to its companion discriminatory harm. ${ }^{11}$ German law, for instance, defines sexual harassment as an intentional activity of a sexual nature that is at least in part recognizably rejected or proven unwelcome and that violates the dignity of individuals at work. ${ }^{12}$ Furthermore, some countries, such as France, have specifically rejected efforts to associate sexual harassment with discrimination, and have ultimately adopted laws that expressly avoid any reference to gender equality in the context of sexual harassment. ${ }^{13}$

This focus on dignity rather than equality in continental Europe is usually attributed to two major factors. First, some commentators argue that doctrinal

resolution was adopted as a result of a 1988 report of the Commission of the European Community on "The Dignity of Women at Work," which concluded that there were still almost no legal initiatives relating to sexual harassment among member states. See Bernstein, supra note 3, at 1237-38.

9. Commission Recommendation 92/131/EEC of 27 November 1991, 1992 O.J. (L 49), available at http://eur-lex.europa.eu/en/index.htm (on the protection of the dignity of women and men at work). The relevant section reads:

Whereas unwanted conduct of a sexual nature, or other conduct based on sex affecting the dignity of women and men at work, including the conduct of superiors and colleagues, is unacceptable and may, in certain circumstances be contrary to the principle of equal treatment within the meaning of Articles 3, 4 and 5 of the Council Directive 76/207/EEC of 9 February 1976 on the implementation of the principle of equal treatment for men and women as regards access to employment, vocational training and promotion, and working conditions....

Id. A Commission recommendation does not bind member states or their citizens. Nevertheless, national courts within the European Community are obliged to take recommendations into account when adjudicating disputes. See Case 322/88, Grimaldi v. Fonds des Maladies Professionnelles, 1989 E.C.R. 4407,4421 .

10. This principle was articulated in two directives that were based on section 13 of the European Treaty: Council Directive 2000/43/EC of 29 June 2000, 2000 O.J. (L 180) 22 (implementing the principle of equal treatment between persons irrespective of racial or ethnic origin); and Council Directive 2000/78/EC of 27 November 2000, 2000 O.J. (L 303) 16, available at http://eurlex.europa.eu/en/index.htm (establishing a general framework for equal treatment in employment and occupation).

11. For a detailed summary of dignity-based legislative initiatives in the area of harassment law across Europe, see Brady Coleman, Pragmatism's Insult: The Growing Interdisciplinary Challenge to American Harassment Jurisprudence, 8 EMP. RTS. \& EMP. POL'Y J. 239, 260-65 (2004). Sexual harassment as sex discrimination has taken hold in British caselaw and has achieved partial endorsement at the Community level and in scattered areas around the continent. See Bernstein, supra note 3, at 124344.

12. Baer, supra note 3, at 590; Vicki Schultz et al., Global Perspectives on Workplace Harassment Law: Proceedings of the 2004 Annual Meeting, Association of American Law Schools Section On Labor Relations and Employment Law, 8 EMP. RTS. \& EMP. POL'Y J. 151, 154-61 (2004).

13. See Abigail C. Saguy, Employment Discrimination or Sexual Violence?: Defining Sexual Harassment in American and French Law, 34 L. \& SoC'Y REV. 1091 (2000). 
differences in this context reflect cultural differences that are similarly evident in other places throughout the law. ${ }^{14}$ Dignity is a well-established value and prime concern in continental European culture due to the fact that "continental law has developed in the shadow of a long history of resentment of statusdifferences of the past." 15 This principle appears in various legal contexts such as European employment law, which is "driven by the idea that European workers, like all formerly low-status persons, are now entitled to 'respect.",16 The central role of dignity in continental European culture and law is reflected in its consensual constitutional status. ${ }^{17}$ The German Constitution (Basic Law) refers to human dignity as the first and most fundamental individual right. ${ }^{18}$ Many other member states of the European Union, such as Belgium, Greece, Italy, Portugal, and Spain, have included a right to dignity in their constitutions. $^{19}$ Similarly, the newly-proclaimed European Charter of Fundamental Rights opens with a right to dignity. ${ }^{20}$

A second factor that some scholars consider relevant to the continental European tendency to define sexual harassment as a dignitary harm rather than as a form of discrimination is the lessened recognition in Europe of the relationship between sexual harassment and sex-based discrimination. A few studies that explored the evolution of sexual harassment law in continental Europe concluded that, in countries such as France or Germany, dignity was perceived as providing a clearer and a more understandable definition of the harm associated with sexual harassment than gender equality. ${ }^{21}$ In other words, once confronted with instances of workplace abuse and humiliation in the form

14. Baer, supra note 3, at 589; Bernstein, supra note 3; Saguy, supra note 13.

15. Friedman \& Whitman, supra note 5 , at 267 . Friedman and Whitman further explain in this context that:

[C]ontinental countries are places where high-status persons used to lord status-differences over their inferiors in insulting and degrading ways. As a reaction against this history, continental law now often aims to guarantee that all persons will be treated with respect. This is an urge that shows up in various areas of the law such as the law of insult, the law of hate speech....

Id.; see also James Q. Whitman, The Two Western Cultures of Privacy: Dignity Versus Liberty, 113 YALE L.J. 1151, 1164-71 (2004) (discussing the centrality of the right to respect and personal dignity in European culture and law).

16. Friedman \& Whitman, supra note 5 , at 267.

17. Baer, supra note 3 , at 589 .

18. Article I, Section 1 of the Basic Law reads, "Human Dignity shall be inviolable. To respect and protect it shall be the duty of all state authority." GRUNDGESETZ [GG] [Constitution] art. $1 \S 1$ (F.R.G.), translated in DONALD KOMMERS, THE CONSTITUTIONAL JURISPRUDENCE OF THE FEDERAL REPUBLIC OF GERMANY 507 (2d ed. 1997). This strong emphasis on dignity as a fundamental human right correlates more broadly to the German understanding of harm developed after 1945, when human dignity came to symbolize the harm of the worst kind that had occurred. See Baer, supra note 3, at 589.

19. DE BELGISCHE GRONDEWET [Constitution] art. 23 (Belg.); 1975 SYNTAGMA [SYN] [Constitution] 2 (Greece); COSTITUZIONE [Constitution] arts. 2, 41 (Italy); CONSTITUIÇÃo [Constitution] art. I (Port.); ConstituCión [C.E.] art. 10 (Spain); REgeringsformen [RF] [Constitution] 2:1 (Swed.); see Baer, supra note 3, at 589 n.39.

20. Article 1 reads, "Human dignity is inviolable. It must be respected and protected." 2000 O.J. (C 364) 9, available at http://www.europarl.europa.eu/charter/pdf/text_en.pdf.

21. Abigall C. Saguy, What is Sexual harassment? From Capitol Hill to the Sorbonne $42(2003)$ 
of sexual harassment, many Europeans understood those instances first and foremost as injuries to personal dignity. Abigail Saguy, who investigated the evolution of sexual harassment law in France, points out that, at least in the French context, this perceptional difference between the European and American approaches to sexual harassment is coupled with an anti-American sentiment that, in France, often regards American society as puritanical. ${ }^{22}$ She explains that when penal reform in 1991 provided an opportunity for French feminists to propose a new penal law on sexual harassment, the original proposal did declare that sexual harassment was based on sex and could compromise equality in employment. Yet while French proponents of this proposal drew on the legal analysis of North American feminists to strengthen their platform, "their opponents used anti-American rhetoric to discredit the bill as an import that would replicate American excesses of litigiousness, Puritanism, and the battle of the sexes in France." Such anti-American rhetoric provided justification for employing a dignitary approach to sexual harassment that was painted as a more realistic definition of sexual harassment, and therefore supported a general failure to understand and codify sexual harassment as gender discrimination. ${ }^{23}$

The dignitary aspects of sexual harassment law in Europe attracted the attention of a few American feminists starting in the 1990s. Growing interest in the comparative aspects of sexual harassment law, coupled with critiques of American sexual harassment caselaw, shifted some of the focus across the

22. Saguy, supra note 13 , at 1114.

23. Abigail Saguy, French and American Lawyers Define Sexual Harassment, in DIRECTIONS IN SEXUAL HARASSMENT LAW, supra note 3, at 602, 605. After review, the National Assembly's Commission on Laws moved the sexual harassment bill out of the section on discrimination and into the rubric of "sexual violence other than rape." Under this legal structure, sexual harassment was legally categorized primarily as a deviant individual attack that is physically, psychologically, or morally harmful and violates the victim's free will, rather than as a form of group-based discrimination. SAGUY, supra note 21 , at 44 . A recent penal reform further emphasized this dignitary paradigm of sexual harassment. In 2002, the French Penal Code was modified to include a paragraph criminalizing all forms of harassment that can impair "the rights and dignity" of any employee. French lawmakers inscribed the following statute into the penal code:

The act of harassing another with repeated actions having as object or effect degradation of work conditions susceptible to undermining that person's rights and dignity, altering that person's physical or mental health, or compromising their professional future, is punished by [a maximum of] one year of imprisonment and [a maximum] fine of 15,000 euros.

C. PEN. art. 222-33-2 (Fr.), translated in SAGUY, supra note 21, at 147. The main object of this reform was to prohibit the newly conceptualized problem of "moral harassment." Moral harassment refers to any form of interpersonal violence or abuse among coworkers; this perspective views sexual harassment as one category of this broader phenomenon of harassment that has no group-based dimension and is strictly understood as individual dignitary harm. For a comprehensive discussion of the concept of moral harassment and its distinction from sexual harassment, see SAGUY, supra note 21, at 144-51; Friedman \& Whitman, supra note 5, at 246-62; Maria Isabel S. Guerrero, The Development of Moral Harassment (or Mobbing) Law in Sweden and France as a Step Towards EU Legislation, 27 B.C. INT'L \& COMP. L. REV. 477, 488-93 (2004); and Rachel A. Yuen, Beyond the Schoolyard: Workplace Bullying and Moral Harassment Law in France and Quebec, 38 CORNELL INT'L. L.J. 625, 634-41 (2005). By positioning sexual harassment within the framework of moral harassment, this amendment reinforced the framing of sexual harassment as a dignity-based phenomenon rather than a form of group-based employment discrimination. 
Atlantic. In one of the first scholarly efforts to reexamine American workplace sexual harassment in light of the European example, Anita Bernstein tried to highlight possible European contributions to the discussion and analysis of sexual harassment. ${ }^{24}$ Among other things, Bernstein identified the role of dignity in the European context and examined the pragmatic advantages of linking sexual harassment with such a concept. Her claim was that such linkage provided a conceptual advantage, since "[a]ppeals to 'dignity' may resonate with persons who cannot listen to 'feminism,' 'women's rights,' 'sexism,' 'sexual harassment,' and the like."25 Furthermore, Bernstein also argued that as a familiar and well-rooted concept, dignity, provided a clearer expression of the harm associated with sexual harassment. In her view, the dignitary harm of harassment could be better understood in reference to the broader history of documented unjust treatment of workers and the more general issue of workers' rights. $^{26}$

In Treating Sexual Harassment with Respect, Bernstein further elaborated on this theme, explaining the normative contribution of the concepts of dignity and respect to the analysis of sexual harassment. ${ }^{27}$ She claimed that "hostile environment sexual harassment" is fundamentally a dignitary harm-a form of "incivility" and "disrespect." 28 She therefore suggested shifting the focus of sexual harassment doctrine away from the "reasonable victim" standard" to the "respectful person" standard. ${ }^{30}$ Instead of focusing on the victim's perspective and requiring plaintiffs to prove that a "reasonable person" would also find the environment hostile or abusive, her idea was to shift the focus of evaluation to require plaintiffs in hostile environment complaints to prove that the harasser "did not conform to the standard of a respectful person." 31 Drawing on both philosophical discussions of the norm of respect ${ }^{32}$ and on the common-sense understanding of sexual harassment, ${ }^{33}$ she concluded that, since "a respectful person does not humiliate another person" but rather "appreciates the dignity of [others],"34 integrating a standard of respect into the analysis of sexual harassment would make it easier to identify prohibited forms of harassment. ${ }^{35}$

24. Bernstein, supra note 3.

25. Id. at 1263 .

26. Id. at 1263-64.

27. Anita Bernstein, Treating Sexual Harassment with Respect, 111 HARV. L. REV. 445 (1997).

28. Id at 450 .

29. The "reasonable victim" or the "reasonable person" standard was first articulated by the United States Supreme Court in Harris v. Forklift Sys., Inc., 510 U.S. 17, 21 (1993). In refining its standards for hostile environment sexual harassment, the Court decided that, to be actionable, an environment of sexual harassment had to be "objectively hostile"-one that a "reasonable person would find hostile or abusive"-as well as hostile to the plaintiff herself. $I d$.

30. Bernstein, supra note 27 , at 454 .

31. Id. at 503 .

32. Id. at 483-92.

33. Id. at 521-24.

34. Id. at 524 .

35. Id. at 524-27. 
Moreover, compared to "reasonableness," she perceived "respect" as a concept that is less burdened with gender-biased entailments. ${ }^{36}$

In the late 1990s, following Bernstein's dignity-based challenge to the standard under which sexual harassment complaints are evaluated in the United States, Rosa Ehrenreich argued for a tort law supplement to Title VII doctrine.$^{37}$ In her view, excessive reliance on Title VII had led scholars to overlook the fact that workplace harassment is fundamentally a dignitary harm. ${ }^{38}$ More specifically, she claimed that many incidents of sexual harassment involve actions that humiliate, torment, threaten, intimidate, pressure, demean, frighten, outrage, or injure a reasonable person and are therefore actions that can be said to injure an individual's dignitary interests in a manner that can give rise to causes of action in tort. ${ }^{39}$ She therefore suggested balancing Title VII, with its emphasis on sex discrimination, with an equal focus on the dignitary harms inherent in certain aspects of harassment. ${ }^{40}$ In her opinion, this additional focus would permit the development of broad, tortbased remedies for the many kinds of non-discriminatory and non-sexual harms to dignity that injure both men and women in the workplace. ${ }^{41}$ Within this new expanded framework of analysis, it would be possible to apply tort-based causes of action to cases of sexual harassment that do not appear to be motivated by sex discrimination, while cases motivated by sex discrimination could continue to be brought under Title VII. ${ }^{42}$

Both Bernstein and Ehrenreich believed that sexual harassment law should identify and address the dignitary harm involved in many incidents of sexual harassment. Yet, rather than seeking to duplicate the European model with its sole focus on dignity, they sought to create a more diversified understanding of sexual harassment. Contrary to other American scholars who contested the discrimination paradigm of sexual harassment altogether, sometimes out of a

36. Id. at $464-71,525$.

37. Rosa Ehrenreich, Dignity and Discrimination: Toward a Pluralistic Understanding of Workplace Harassment, 88 GEO. L.J. 1 (1999).

38. Id. at 14-16.

39. Id. at 22 .

40. Id. at 53-60.

41. $I d$.

42. Id. at 60-64. In summarizing her position, Ehrenreich explained:

A pluralistic understanding of workplace harassment-one that embraces both common law torts and Title VII within its ambit-has three important benefits. First, such a pluralistic approach allows for a legal remedy for the many workers who experience severe harassment on the job, but who would be hard pressed to assert that their harassment was "because of sex," as required by even the most expansive reading of Title VII. Second, a pluralistic approach keeps the focus of Title VII where it should be: on addressing the problem of widespread workplace discrimination against members of discrete and vulnerable groups .... Third, grounding understanding of the sexual harassment of women in a notion of dignitary harm as well as in a discrimination paradigm makes a critical political and philosophical point: Workplace harassment of women is wrong not because women are women, but because women are human beings and share with all other human beings the Id. at 60 right to be treated with respect and concern. 
specific rejection of feminist arguments regarding an inherent link between sexual harassment and gender inequality, ${ }^{43}$ both Bernstein and Ehrenreich sought to strengthen, not undermine, the feminist position against sexual harassment. They argued not for replacing the traditional paradigm of discrimination but for supplementing it, so that in addition to gender equality, dignity too would provide a relevant reference for understanding the wrongs of sexual harassment. In the United States, however, this suggestion to divert the focus of harassment law from discrimination to dignity has remained a hypothetical challenge, endorsed in later years by some new proponents and vigorously opposed by others. ${ }^{44}$

In Israel, on the other hand, reframing the discussion of sexual harassment in dignitary terms has had a serious practical impact. It has contributed to legal reforms that officially recognized dignity as a primary value for the analysis of sexual harassment and its harms. The Israeli law formally resembles some European laws dealing with sexual harassment, and, as discussed in Part II, similar factors played a role in shaping sexual harassment law in Europe and Israel. However, Israeli law aspired to achieve the more complicated task that American scholars like Bernstein and Ehrenreich envisioned: to create a more diversified understanding of sexual harassment that truly combines dignity and gender equality in the analysis of this phenomenon and its harms.

\section{ISRAEL'S PREVENTION OF SEXUAL HARASSMENT LAW-A NEW APPROACH TO AN OLD PROBLEM}

\section{A. General Background}

The Prevention of Sexual Harassment Law of 1998 was not the first Israeli attempt to cope with the problem of sexual harassment. The Equal Employment Opportunity Law of $1988^{45}$ (EEOL) that was enacted a decade earlier provided

43. Mark McLaughlin Hager, Harassment As a Tort: Why Title VII Hostile Environment Liability Should Be Curtailed, 30 CONN. L. REV. 375 (1998); Ellen Frankel Paul, Sexual Harassment as Sex Discrimination: A Defective Paradigm, 8 YALE L. \& POL'Y REV. 333 (1990).

44. The most elaborated critique of Bernstein's dignitary challenge to sexual harassment law was articulated by Kathryn Abrams. See Kathryn Abrams, The New Jurisprudence of Sexual Harassment, 83 CORNELL L. REV. 1169 (1998). For the full exchange between Abrams and Bernstein, see Kathryn Abrams, Postscript, Spring 1998: A Response to Professors Bernstein and Franke, 83 CORNELL L. REV. 1257 (1998); and Anita Bernstein, An Old Jurisprudence: Respect in Retrospect, 83 CORNELL L. REV. 1231 (1998). In recent years, with the growing interest among American scholars in the newly conceptualized problem of "moral harassment" (or workplace bullying) in Europe, some have argued that a non-status based approach to harassment that focuses on the individual dignitary harm of harassment at work will benefit women as well as other protected groups. More specifically, the claim is that harassment of workers is not always about sex or race and therefore general, status-blind hostile environment protection will provide better protection for all workers, including women, against any form of interpersonal violence or abuse at work. See Coleman, supra note 11; David C. Yamada, The Phenomenon of "Workplace Bullying" and the Need for Status-Blind Hostile Work Environment Protection, 88 GEO. L.J. 475 (2000); see also Saguy, supra note 21, at 145-50.

45. Equal Employment Opportunity Law, 1988, S.H. 38 (Isr.). 
partial protection against sexual harassment. This early legislation defined sexual harassment very narrowly. Section 7 of the EEOL prohibited employers from mistreating employees who had refused or objected to propositions or acts of a sexual nature initiated by the employer or supervisor. ${ }^{46}$ In other words, this section forbade the disparate treatment of workers who objected to sexual propositions, but did not independently prohibit these sexual propositions or behaviors. By barring retaliation against sexually harassed employees in the context of an equal employment opportunity law, legislators implicitly linked sexual harassment with sex-based discrimination. This framework was influenced by the American conceptualization of sexual harassment as discrimination prohibited by Title VII. ${ }^{47}$ However, despite the formal reference to discrimination, the legislative history of the EEOL reveals that those involved in this initial legislative process rejected the possibility of defining sexual harassment as a discriminatory practice because the relationship between sexual harassment and sex-based discrimination was unclear to many legislators. ${ }^{48}$ The only aspect of discrimination they identified in this context was quid pro quo harassment, where an employer took discriminatory action against an employee who refused his or her sexual proposals by denying an employment right. Within this legal framework, the very subjection of an employee to harassing sexual demands or to hostile environment sexual harassment was not defined as a prohibited behavior at all. Sexual harassment was prohibited under the EEOL only with regard to some of its forms and only when the legislature had managed to explicitly connect those forms to the notion of sex-based discrimination. ${ }^{49}$ This formal rejection of a substantive link between many forms of sexual harassment and sex-based discrimination resulted in the litigation of very few cases in the years following the original law's enactment. ${ }^{50}$

Some Israeli feminist groups and individuals felt that something was amiss. Hoping to correct the EEOL's deficiencies, these groups and individuals

46. Such protection was afforded only in listed areas: hiring, work conditions, promotions, training and professional development, firing, and compensation for dismissal. Id. $\S \S 2,7$.

47. Rachel Benziman, Sexual Harassment at the Workplace, in WOMEN's STATUS IN ISRAELI LAW AND SOCIETY 318, 326-28 (Frances Raday, Carmel Shalev \& Michal Liban Kooby eds., 1995); Orit Kamir, Rethinking Sexual Harassment in Terms of Human Dignity-Respect, 29 MishPATIM 317, 362 (1998) (Isr.).

48. Orit Kamir, who investigated the legislative history of the EEOL, concluded:

The legislative process of 1988 reveals that as part of the general view of the Israeli parliament and maybe of the Israeli society in general, the phenomenon of sexual harassment is not perceived as a violation of sex-based equality, and even as not exclusively relevant to the employment context.

Orit Kamir, supra note 47 , at 373. For a detailed analysis of the legislative history of the sexual harassment section that was eventually included in the EEOL, see id. at 361-73.

49. See supra note $\mathbf{4 6}$ and accompanying text.

50. See Benziman, supra note 47, at 338; Orit Kamir, Dignity, Respect, and Equality in Israel's Sexual Harassment Law, in DiRECTIONS in SEXUAL HARASSMENT LAW, supra note 3, at 561, 562. 
proposed a new model law for the prevention of sexual harassment. ${ }^{51}$ One of the leading feminist forces behind the new legislation was law professor Orit Kamir. She was joined by Rachel Benziman, the legal advisor of the Women's Network. Other feminist groups and individuals who were partners in the legislative process were law professors Ruth Ben-Israel and Frances Raday and the women's organizations Wizo and Na'amat. ${ }^{52}$ The Ministry of Justice and the Parliamentary Committee on the Status of Women adopted the proposed model law and this legislative proposal served as the basis for the parliamentary formulation of Israel's Prevention of Sexual Harassment Law, ${ }^{53}$ which was enacted in $1998 .^{54}$

The Prevention of Sexual Harassment Law provides a broader conceptual framework for the analysis of sexual harassment than the 1988 EEOL in two substantive areas. First, the law contains detailed definitions of several types of sexually harassing behaviors, ${ }^{55}$ and provides for civil and criminal sanctions for each type of such behavior ${ }^{56}$ in social settings such as the street, the educational system, or the military-not only in the workplace. ${ }^{57}$ Hence the new law

51. Kamir, supra note 50 , at 562 .

52. For a detailed analysis of the role of Israeli feminist groups and individuals in the legislative process, see Noya Rimalt, On Sex. Sexuality and Human Dignity: The Law for the Prevention of Sexual Harassment in Light of Feminist Theory and Legal Reality, 35 MiSHPATIM 601, 606-1 1 (2005) (Isr.).

53. Id.

54. Prevention of Sexual Harassment Law, 1998, S.H. 166 (Isr.).

55. Section 3(a) provides:

(a) Each of the following acts constitutes sexual harassment:

(1) extortion by threats, as defined in section 428 of the Penal Law, where the act demanded to be performed by the person is of a sexual character;

(2) indecent acts, as defined in sections 348 and 349 of the Penal Law;

(3) repeated propositions of a sexual nature, addressed to a person, who demonstrated to the harasser that he is not interested in the said propositions;

(4) repeated references directed towards a person, and focus on his sexuality, where that person demonstrated to the harasser that he is not interested in the said references;

(5) a degrading or humiliating reference to a person concerning his gender, or sexuality, including his sexual orientation;

(6) propositions or references as described in subsections (3) or (4), directed towards one of those enumerated in subsections (a) to (e), in such circumstances as specified in such subsections, even if the harassed person did not demonstrate to the harasser that he is not interested in the said propositions or references: (a) toward a minor or a helpless person, where a relationship of authority, dependence, education or treatment is being exploited; (b) toward a patient undergoing mental or medical treatment, where a relationship of dependence between the patient and the person treating him is being exploited; (c) toward an employee within the framework of an employment relationship, and toward a person on service within the framework of a service-where a position of authority in a work relationship or in service is being exploited; (d) toward a pupil in the 12th, 13th or 14th grade who is not a minor, where a relationship of authority is being exploited at school; (e) toward a pupil or student, who studies at an institution that provides academic or vocational training for adults (in this Law: adult education institution) where a relationship of authority is being exploited at school.

Id. $\$ 3$.

56. Under section 6 , all types of sexual harassment defined in section 3 constitute civil wrongs. All of them (except blackmail by way of threats and indecent acts, which are already prohibited by the Israeli Penal Law) are also defined in section 5 of the law as criminal offenses. The criminal sanction set out in section 5 is two years of imprisonment for sexual harassment, three years for related intimidation, and four years for both sexual harassment and related intimidation. Id.

57. The law provides a general prohibition against sexual harassment that is not restricted to a particular context. Section 4 states: "A person shall not sexually harass another person and shall not 
constitutes both a civil and a criminal prohibition against sexual harassment that is not restricted to the employment context. Second, the Prevention of Sexual Harassment Law reconceptualizes sexual harassment primarily as a dignitary harm. Unlike American law, the Israeli law refers to the discriminatory aspect of this social practice as an additional (rather than exclusive) feature of the wrong of sexual harassment. Section 1 states the law's objective: "to prohibit sexual harassment, in order to protect human dignity, liberty and privacy and to promote equality between the sexes."58

\section{B. Relevant Features and Underlying Rationales}

In initiating conceptual reforms in sexual harassment law, Israeli feminists who promoted the Prevention of Sexual Harassment Law relied on a range of arguments. Their decision to emphasize sexual harassment's harm to human dignity, rather than its harm to equality, was due to pragmatic as well as substantive reasoning.

First, due to the significant political influence of Jewish Orthodox parties, equality is not a fully recognized constitutional right in Israel. ${ }^{59}$ On the other hand, the right to human dignity, respect, and honor has recently gained constitutional status in Israel. ${ }^{60}$ The Basic Law: Human Dignity and Liberty, ${ }^{61}$ which is now generally accepted as part of Israel's "semi-constitution," refers to this assembly of values as the foundation of the Israeli legal system. ${ }^{62}$

retaliate against another person." Retaliation is defined in section 3(b) as "any injury that stems from sexual harassment or from a complaint or suit submitted because of sexual harassment." Section 11 clarifies that the law's provisions apply to the State and the Civil Service, and that all security forces (the Israeli Defense Forces, the Israeli Police, the Prison Service, and all other defense organizations of the State) will be deemed as employers and the persons serving in them as employees. Id. Hence, the combination of sections 4 and 11 provides a general prohibition against sexual harassment that is applicable in all possible contexts.

58. Id. $\$ 1$.

59. Israel does not have a comprehensive bill of rights, nor does Israel maintain a separation between church and state, but instead applies the rule of religious law in the area of family law. Since religious systems of law-and especially Jewish law and Muslim Law-often discriminate against women, no full constitutional equality for women can be guaranteed under the current Israeli legal framework. Until now, all efforts to enact a comprehensive bill of rights that would formally include the right to equality have failed. For a description of the status of equality in the Israeli legal system, see RUTH HALPERIN-KADDARI, WOMEN IN ISRAEL 24-42 (2004).

60. The Hebrew language does not formally distinguish between the terms dignity, honor, and respect. The word "kavod" is the only Hebrew term that corresponds to the English words "honor," "dignity," and "respect." Therefore, when the Israeli legislature enacted the right to "kavod" as a basic right, it granted a constitutional status to this complex assembly of values. See Basic Law: Human Dignity and Liberty, 5752-1992, 1391 LSI 150 (1992) (Isr.). For a detailed analysis of this linguistic aspect of the term "kavod" and its significance in the context of the Prevention of Sexual Harassment Law, see infra Section II.C.

61. Basic Law: Human Dignity and Liberty, 5752-1992, 1391 LSI 150 (1992) (Isr.).

62. In the early $1990 \mathrm{~s}$, instead of a comprehensive written constitution, Israel enacted two new "Basic Laws" that address human rights guarantees: Basic Law: Human Dignity and Liberty, id., and Basic Law: Freedom of Occupation, 5752-1992, 1454 LSI 90 (1992) (Isr.). These laws were designed to eventually be codified into a comprehensive bill of rights. Therefore, the Israeli Supreme Court 
Similar to some continental European countries, Israel has thus awarded a special constitutional status to the value of human dignity. In light of these legal developments, feminist proponents of the new law concluded that devising a culturally sensitive item of legislation based on accepted and constitutionally-anchored values and norms would make the prohibition against sexual harassment more effective. ${ }^{63}$

Second, drawing on American sexual harassment caselaw and legislation, ${ }^{64}$ Israeli feminists focused on what they perceived as major drawbacks in the American Title VII model. ${ }^{65}$ Professor Orit Kamir argued that one of the deficiencies of the U.S. model is the exclusive association of sexual harassment with sex-based discrimination. ${ }^{66}$ Adopting arguments previously made by American scholars such as Katherine Franke, ${ }^{67}$ she claimed that the substantial link between sexual harassment and discrimination-derived from Catharine MacKinnon's work on sexual harassment-has proven to be very problematic in its adoption by the courts. MacKinnon's radical notion of equality based on a theory of gender subordination ${ }^{68}$ was "too complicated or too radical for most judges. " ${ }^{, 69}$ Instead of adopting MacKinnon's subordination argument, which is "necessary to make the logical bridge" between sexually harassing behavior and gender discrimination, American judges have concluded that sexual harassment is sex discrimination only when it violates the formal equality principle of equal treatment to those who are similarly situated. ${ }^{70}$ In other words, while MacKinnon focused on the disparate impact of sexual harassment and articulated how sexual harassment institutionalized the sexual subordination of women, American courts framed the problem as one of equal treatment and determined that the critical issue "is whether members of one sex are exposed to disadvantageous terms or conditions of employment to which members of the other sex are not exposed."71 In Kamir's view this explanation

\footnotetext{
interpreted these new basic laws as granting the judiciary the power to strike down any legislation that violates the basic rights guaranteed by the two Basic Laws. However, according to specific provisions in the Basic Laws, this judicial power is restricted to laws passed after the enactment of these Basic Laws. RUTH HALPERIN-KADDARI, supra note 59, at 24-25.

63. Kamir, supra note 50 , at 568 .

64. Id.

65. Id.

66. Id. at 564-65.

67. Katherine M. Franke, What's Wrong with Sexual Harassment?, 49 STAN. L. REv. 691 (1997).

68. MacKinnon argues that the anti-subordination or the inequality approach best explains the harm of sexual harassment when applied to women's working lives and has the greatest potential to transform sexually discriminatory workplace practices through the use of law. In her view, "a rule or practice is discriminatory, in the inequality approach, if it participates in the systematic social deprivation of one sex because of sex." CATHARINE MACKINNON, SEXUAl HARASSMENT OF WORKING WOMEN: A CASE OF SEX DISCRIMINATION 117 (1979). Therefore, sexual harassment is sex discrimination because it helps create and further inequality between the sexes by perpetuating the interlocked structure through which women have been kept sexually in thrall to men and at the bottom of the labor market. $I d$. at 174-92.

69. Franke, supra note 67 , at 729.

70. Kamir, supra note 50 , at 565 .

71. Harris v. Forklift Sys., Inc., 510 U.S. 17, 25 (1993) (Ginsburg, J., concurring).
} 
worked well in cases where heterosexual men harass women, ${ }^{72}$ but worked less well in cases such as that of the "equal opportunity harasser": the person who harasses both men and women. ${ }^{73}$ In such cases, judges could logically argue that no one had been treated differently on the basis of gender, and that, therefore, no discrimination occurred. ${ }^{74}$ Moreover, relying on MacKinnon's critique regarding the inherently male-biased nature of formal equality, ${ }^{75} \mathrm{Kamir}$ argued that this formal equality "does not and cannot remedy women who suffer from sex discrimination, for the simple reason that, under patriarchy women are not "similarly situated' to men."76 Based on this analysis, Israeli feminists worried that the prevalent judicial notion of formal equality, deeply embedded as it is in conservative thought, might restrict the development of sexual harassment law. ${ }^{77}$ They worried that this limited understanding of the relationship between sexual harassment and sex-based discrimination was likely to be "incoherent, unconvincing and at times ineffective," 78 leading to an inadequate definition of the harms of sexual harassment. As opposed to equality, Israeli feminists claimed that dignity or respect were less entangled in gendered controversies and therefore provided a more promising conceptual framework for the analysis of sexual harassment. ${ }^{79}$ Hence, the Israeli conclusion was that new sexual harassment legislation would profit from association with other social values (besides equality), primarily human dignity and respect. While MacKinnon aspired to promote a substantive concept of sex equality based on the anti-subordination or the inequality approach, ${ }^{80}$ feminist

72. Kamir, supra note 50.

73. Id. The problem of the "equal opportunity harasser" and the manner in which this phenomenon challenges a concept of sex discrimination based on formal equality principles is discussed in the works of other commentators. See, e.g., Ehrenreich, supra note 37, at 9. Katherine Franke makes a similar argument with regard to same-sex harassment and claims that the courts' formal conception of sex discrimination is unable to provide a satisfactory account of the discriminatory wrong of same-sex sexual harassment. See Franke, supra note 67.

74. Kamir, supra note 50 , at 565 . However, it should be noted that in practice very few alleged harassers have sought to raise this defense. As Kenji Yoshino observes in this context, "Such defendants appear more often in fiction or hypotheticals than actual litigation; the defense has been raised in only two cases and has been rejected in both." Kenji Yoshino, The Epistemic Contract of Bisexual Erasure, 52 STAN. L. REV. 353, 443 (2000).

75. In explaining the limits of formal equality according to which similarly situated people deserve similar treatment, MacKinnon argued,

To define the reality of sex as difference and the warrant of equality as sameness is wrong on both counts.... Once this is done, to require that one be the same as those who set the standard - those which one is already socially defined as different from-simply means that sex equality is conceptually designed never to be achieved. Those who most need equal treatment will be the least similar, socially, to those whose situation sets the standard as against which one's entitlement to be equally treated is measured. Doctrinally speaking, the deepest problems of sex inequality will not find women 'similarly situated to men.'

CATHARINe A. MACKINNON, Difference and Dominance: On Sex Discrimination, in FeMINISM UNMODIFIED 32, 44 (1987).

76. Kamir, supra note 50 , at 565.

77. Id.

78. Id.

79. Id.

80. See MacKinnon, supra note 75 and accompanying text. 
proponents of the new legislation concluded that diverting the focus of the new law from sex equality to human dignity would provide a better solution to the problem of "patriarchal" equality since values like human dignity are less entwined with conservative and patriarchal thought. ${ }^{81}$

An additional argument in this context was that values such as dignity tie in more with the common-sense understanding of the wrong of sexual harassment as a dignitary harm. ${ }^{82}$ Orit Kamir specifically explained, in this context, that:

The advantage of the proposed definition is that within its framework, the prohibition on sexual harassment means: "do not behave in a sexual manner that violates a person's dignity and liberty." Despite the fact that such a command seems broad and not specific, it appears to me that in the current Israeli context, it has a very clear meaning. ${ }^{83}$

The arguments regarding the pragmatic advantages of the dignitary paradigm of sexual harassment law were supplemented with a more substantive defense of this paradigmatic shift. Similar to scholars like Bernstein and Ehrenreich, Kamir and other feminist proponents of the dignity-based aspects of the new law adopted the European normative claim that sexual harassment is primarily a form of disrespect to women, and that its conceptualization as a dignitary harm truly characterizes an important aspect of this social practice. Also, in line with American feminists and contrary to the European model, Israeli feminists did not aspire to replace equality with dignity, but only to supplement and to enrich the discussion of sexual harassment and its harms. Kamir claimed that conceptualizing sexual harassment in terms of dignity and respect does not require-and in fact should not lead to- "its separation from notions of equality": 84

Dignity, respect, liberty, and equality need not be posed as competing or exclusionary values; on the contrary, in the context of sexual harassment law, they should rather be read as complementary. Sexual harassment discriminates against women by not respecting them as women and as human beings, by violating their dignity, and by restricting their liberty to determine themselves and to lead lives free of fear and restriction. It disrespects women and violates their dignity by mirroring and perpetuating a social reality that does not treat them as equal. The more commonsense notions of dignity, respect, and liberty can be useful in conveying the harm caused by sexual harassment, and in illuminating its sex-discriminatory harm. ${ }^{85}$

81. Kamir, supra note 50.

82. Kamir, supra note 50 , at 376 .

83. Id.

84. Kamir, supra note 50 , at 568 .

85. Id. (citations omitted). 
The explanatory note ${ }^{86}$ attached to the proposed legislation stressed this ideological point, linking the degradation to dignity that results from sexual harassment to a notion of gender equality. ${ }^{87}$ This note depicted sexual harassment as an offense that humiliates its victims, degrades them, and invades their privacy, ${ }^{88}$ and added that "the sexual harassment of women humiliates them in relation to their sex or sexuality, and hinders their ability to enter the workforce and other areas of life as equal members, and as such hurts their equality." 89 The new law itself emphasized this dignity-equality nexus and declared in section 1 that its objective was "to prohibit sexual harassment in order to protect human dignity, liberty and privacy and to promote equality between the sexes." 90 Thus, with the enactment of the Prevention of Sexual Harassment Law, what some American scholars had discussed on a theoretical level became a legal reality in Israel.

In addition to this interrelated approach to sexual harassment, the law included a very detailed formal definition of what constitutes sexually harassing behavior and provided both civil and criminal sanctions for each type of behavior. ${ }^{91}$ As opposed to the American Title VII, which contains no definition of sexual harassment, the Israeli law was designed to provide better guidance to the Israeli courts in their efforts to identify prohibited forms of harassment. ${ }^{92}$ The decision to criminalize sexual harassment, in addition to its civil implications, was based on the argument that criminal law is widely considered by Israelis as the most important legal expression of society's fundamental values. ${ }^{93}$ This consideration, in addition to the assumption that criminal laws are both easier to enact and more readily applied by the courts, ${ }^{94}$ led to the criminalization of all forms of sexual harassment alongside their definition as tortious wrongs and labor law violations. This marked another sharp, intentional departure from the American prohibition against sexual harassment contained within Title VII. ${ }^{95}$ In an effort to supply a full and clear definition of the new norm prohibiting sexual harassment and to strengthen the criminal aspect of the law, some sex offenses such as "indecent acts" 96 or "sexual blackmail by way of threats" that were already prohibited by the provisions of the Israeli Penal Law were defined in the 1998 statute as types of

86. Official explanatory notes are drafted by the Ministry of Justice and are attached to a draft law for its first hearing in the Knesset. The notes serve courts as guidelines for interpretation.

87. Draft bill of the Prevention of Sexual Harassment Law, 1997, HH, 484 (on file with author).

88. Id.

89. Id.

90. Prevention of Sexual Harassment Law, 1998, S.H. $166 \S 1$ (Isr.).

91. Id. $\S 3$. For the exact wording of the law, see supra note 55 .

92. See Kamir, supra note 50, at 563-64.

93. Id. at 568 .

94. Id.

95. Id.

96. Prevention of Sexual Harassment Law, 1998, S.H. $166 \S 3(a)$ (2) (Isr.).

97. Id. $\S 3(\mathrm{a})(1)$. 
sexual harassment as well. ${ }^{98}$ This category of sex offenses was integrated into section 3 as the first in a list of behaviors that the law prohibits and denounces.

The feminist campaign for the new legislation was short and successful. Feminist groups and individuals, promoting their idea to replace the existing sexual harassment legislation with a broader statute, sought involvement in the legislative process by approaching the Ministry of Justice and the Knesset Committee for the Advancement of the Status of Women. ${ }^{99}$ The basic conceptual frameworks proposed by this feminist coalition were well received by state officials and The Knesset members involved in the legislative process and served as the basis for the parliamentary formulation of the new Israeli statute. ${ }^{100}$ The Prevention of Sexual Harassment Law was approved by a large majority vote in the predominately conservative Knesset. Most members of the Knesset, ranging from the extreme right and the ultra-orthodox parties to the socially progressive parties, declared their support for the law. ${ }^{101}$ Furthermore, despite the gender-neutral language of the law, both the feminist forces who promoted the legislation and the legislators who drafted the final version of the law and voted for it clearly perceived the new law as aiming to combat a social phenomenon that disproportionately injured women. ${ }^{102}$ As a symbolic and deliberate act, the Knesset approved the final version of the bill on International Women's Day-March 10, 1998-along with another piece of legislation establishing a statutory body in charge of the promotion of women's status in society. ${ }^{103}$

Feminist expectations for the new legislation were tremendous. The Prevention of Sexual Harassment Law was presented as a consciousness-

98. Kamir, supra note 50 , at 570-71.

99. For an account of the feminist forces in Israel who contributed to the formulation of the Prevention of Sexual Harassment Law, see supra note 52 and accompanying text.

100. See supra note 53 and accompanying text.

101. See Tzili Mor, Law as a Tool for a Sexual Revolution: Israel's Prevention of Sexual Harassment Law-1998, 7 MICH. J. GENDER \& L. 291 (2001).

102. The final version of the law was prepared by the Knesset Committee for the Advancement of the Status of Women. The chairperson of the Committee Yael Dayan presented the proposed law to the Knesset before the final vote of approval. During the parliamentary deliberations many members of Knesset (MKs) referred to the new legislation in clearly gendered terms, specifically indicating that the problem the law was designed to combat was predominantly a women's problem. For example, in her introductory presentation to the Israeli Parliament, MK Yael Dayan explained:

[A]nd now we approach legislation that is relevant to everybody. It is relevant to the female soldier and [her] officer. It is relevant to the policewoman and her boss, or her commanding officer in the police force. It is relevant to the female student and her supervisor or professor who teaches her. It is relevant to the female employee and her supervisor, and to the cattitude of the] male worker toward a female worker. That is, we are covering here all possibilities to protect the woman...

Legislative Proposal on the Prevention of Sexual Harassment-1998, Second and Third Reading, DK (1998) 5890,5900 (on file with author). MK Binyamin Elon added, "A woman is not a sexual object, and it is intolerable that there is a cultural attitude of treating a woman as a sexual object when she says please do not talk to me like this." Id. Similar gendered references to the law can be found in the speeches of other Members of Knesset such as Tamar Goznasky, Reuven Rivlin, Anat Maor, and Rechavam Ze'Evi. Id.

103. Authority for the Advancement of the Status of Women Law, 1998, S.H. $171 \S 2$ (Isr.). 
raising tool that would mark a new era in the awareness of this social phenomenon among the Israeli public. ${ }^{104}$ Yet it appears that in building up those expectations, Israeli feminists failed to take full account of the potential implications of the conceptual choices ingrained in the new legislation. They especially neglected to appreciate the full significance of the reconceptualization of sexual harassment primarily as a dignitary harm.

\section{The Dignitary Paradigm of the Prevention of Sexual Harassment Law- Normative Ambiguity and Gendered Implications}

The Hebrew language does not formally distinguish between the terms honor, respect, and dignity. ${ }^{105}$ The word kavod is the only Hebrew term that corresponds to these three terms. There is thus a complexity of meanings and concepts inherent in one term. In Israeli culture and society, as well as in Israeli law, the term 'human dignity' (kavod ha-adam) is inseparable from, while sometimes at variance with, other values representing distinct sentiments and even contradictory value systems. The feminist forces who initiated the reference to the term kavod as an integral component of the dignitary paradigm of the Prevention of Sexual Harassment Law were seeking to capture the modern liberal meaning of that term, and to preserve a substantive link between kavod as human dignity and gender equality. ${ }^{106}$ Gender equality was also mentioned as a separate relevant value in section 1. However, once kavod was integrated into the new legislation, it paved the way for other intuitive concepts associated with this term, some of them deeply entangled with patriarchal ideology and reality. It also created some confusion as to the exact rationale and goals of the new legislation. This normative confusion may have contributed to broad parliamentary support for the new law by a spontaneous coalition of feminists, right-wing conservatives, and religious orthodox groups. ${ }^{107}$ One such unexpected supporter, MK Binyamin Elon--an Orthodox Jew who was a member of the Knesset Committee for the Advancement of the Status of Women, which drafted the final version of the law-summarized the sentiments of many during the parliamentary debate over the proposed law:

This law is good, this law has to pass and it will add delicacy, integrity, honor and gracefulness in Israeli society. . . . To me nobody

104. For instance, shortly after its enactment, Tzili Mor described the new law in the following manner: "Israeli women's rights advocacy groups succeeded in passing one of the most progressive laws in the world." Mor, supra note 101, at 330.

105. The Hebrew-English dictionary translates the word 'kavod' in Hebrew as "honour, respect, glory, splendour [sic] ...." THE COMPLETE HEBREW-English DiCTIONARY 984 (R. Alcalay ed., new enlarged ed. 1990). No other word in Hebrew carries a similar meaning. Hence contemporary Israeli Hebrew does not offer a formal terminology to distinguish between the terms dignity, honor, and respect, as they are all potential meanings of the single term "kavod."

106. Kamir, supra note 50 , at 568 .

107. Mor, supra note 101, at 292. 
will say "honey" and ask me to sleep with them just like that when they pass me in the corridor. But to say this to a woman is permissible. Why? because she is a woman. This is not modest. This 1 find unacceptable. $^{108}$

This supporter of the new law here correlates sexual harassment with a superficial rather than substantive concept of gender equality. Although he was referring to women in particular as the injured group, his notions of the gendered harm caused by sexual harassment seemed to derive from concepts associating kavod with honor rather than with human dignity. Framing the breach of modesty as the main injury of sexual harassment, Elon portrays the proposed legislation as designed to promote delicacy and gracefulness in society on equal terms for both men and women, thus creating a very different rationale for the approval of the Prevention of Sexual Harassment Law than its initiators had in mind. As MK Elon interpreted it, the new law was not intended to advance women's equal rights in the workplace. Instead, he redefined the primary goal of the new law as relating to the protection of women's sexual modesty and to society's interest in preserving this aspect of women's honor.

Against this understanding of kavod as honor, other proponents of the law presented an alternative perception that correlated kavod with "human dignity," as feminist proponents of the new law intended. However, this alternative perception was problematic in a different manner, since it separated dignity from equality and defined sexual harassment in gender-neutral and individual terms. Drora Nachmani-Roth, a senior attorney with the Ministry of Justice who participated in the parliamentary deliberation over the new legislation, explained to other members of the Knesset Committee for the Advancement of the Status of Women, "I believe that in time it will be said that the Sexual Harassment Law is indeed designed to protect a person's privacy that derives from dignity. Only in some aspects is there discrimination."109

It appears that while feminist proponents of the law aspired to promote an integrated understanding of sexual harassment, one that reflects both its dignitary and discriminatory harms, many of their partners in the legislative process did not interpret the proposed legislation in a similar manner. Despite the fact that the official language of the law refers to kavod as well as "the equality between the sexes," it seems that the primary (and often the sole) focus of many proponents was the former term, with its multiple meanings. Some, like MK Elon, adhered to the honor aspect of kavod, thereby interpreting the wrong of sexual harassment in clearly patriarchal terms. Others, like advocate Drora Nachmani-Roth, diverted the discussion to the human dignity aspect of the term, focusing on the elements of neutrality and individuality that typically

108. Legislative Proposal on the Prevention of Sexual Harassment-1998, Second and Third Reading, DK (1998) 5890, 5900 (on file with author).

109. Protocol No. 57: Meeting of the Committee for the Advancement of the Status of Women, 14th Knesset, 2d. Session, June 17, 1997 (Isr.) (on file with author). 
characterize the concept of human dignity. ${ }^{110}$ Despite the fact that feminist proponents, state officials, and The Knesset members all eventually rallied behind the same legislation, those different supporters of the Prevention of Sexual Harassment Law had very different views as to what its dignitary paradigm implied.

The discursive ambiguity, which preceded the enactment of the Prevention of Sexual Harassment Law, sheds light on the court opinions that followed. As will be demonstrated and explained in Part III, Israeli courts in many ways mirror the society they serve in their diverse understandings of the dignitary harm of sexual harassment and in their interpretations of the Prevention of Sexual Harassment Law.

\section{SeXual Harassment CaSelaw-Facts and ANalysis}

The enactment of the Prevention of Sexual Harassment Law in 1998 brought about a marked increase in the number of court opinions dealing with sexual harassment in Israel. The original prohibition against sexual harassment anchored in the 1988 Equal Employment Opportunity Law yielded very few complaints and consequently failed to produce meaningful judicial decisions on sexual harassment over a period of ten years. ${ }^{11}$ My study has identified 222 reported court opinions and decisions ${ }^{112}$ that were issued under the new legislation between March 1998 and September 2006. ${ }^{113}$ These opinions discuss and apply the prohibition against sexual harassment in various areas of the law: criminal, civil, labor, disciplinary procedures against state employees, and military procedures against military personnel. During these years the Supreme Court of Israel interpreted and applied the Prevention of Sexual Harassment Law numerous times (mostly in appellate disciplinary proceedings against state employees who were accused of sexually harassing other

110. Baer, supra note 3 , at 586 .

111. The limited scope of the original prohibition against sexual harassment is most likely the primary explanation for the exceedingly small number of cases litigated in the years before the enactment of the new legislation. See supra notes 46-50 and accompanying text.

112. My study has identified decisions of various judicial bodies including magistrate courts, appellate district courts, labor courts, military courts, disciplinary courts, and the Supreme Court of Israel. Some of the decisions involved the discussion of the same case in two court instances. For instance, in some cases I was able to trace both the magistrate court and the appellate court opinions. In addition, in a few cases I was able to trace only a preliminary decision, possibly because the case was settled or dropped or because the final opinion in the case was not reported. Thus, the total number of 222 reported cases includes multiple court opinions in the same case, and sometimes only a preliminary decision in the case.

113. My review of sexual harassment court cases is comprehensive. 1 ran searches for all reported sexual harassment cases in Israeli courts from the enactment of the Prevention of Sexual Harassment Law in March 1998 until September 13, 2006. While the new legislation came into effect in September 1998, several cases that dealt with incidents of sexual harassment that occurred before that legislation came into effect referred to the new legislation as a source of inspiration and interpretation. The most prominent example is Ben-Asher. See infra notes 118-135 and accompanying text. Those cases therefore became part of the relevant caselaw that I read and analyzed. 
employees), ${ }^{114}$ providing a detailed conceptual frame of reference that has guided lower courts and shaped the nature and substance of judicial discourse on sexual harassment in Israel. In this respect, the new sexual harassment legislation has been very influential, producing a significant body of caselaw in an area that was previously under-recognized and under-discussed in Israel.

However, examining the manner in which Israeli courts have "talked" about sexual harassment and conceptualized its harm ${ }^{115}$ reveals a growing gap between the judge-made analysis of sexual harassment and the original feminist goal behind the Prevention of Sexual Harassment Law. Four major themes characterize contemporary sexual harassment caselaw in Israel. First, the caselaw prioritizes dignity over equality in the discussion of the wrong of sexual harassment so much so that the discriminatory aspects of sexual harassment are excluded from formal legal analysis. In contrast to the original feminist intention of using the new legislation to promote a complex understanding of the harm of sexual harassment based on a dignity-equality nexus, courts have come to interpret the harm of sexual harassment solely in dignitary terms. Second, once dignity becomes the exclusive basis for the wrong of sexual harassment, courts sometimes discuss and explain this harm in gender-neutral and individual terms that ignore and disguise the clear gendered significance of the vast majority of sexual harassment cases. While almost all reported cases in this area involve a male harasser, a female victim, ${ }^{116}$ and a gendered context of unequal power relations between the harasser and the harassed, the courts analyze those cases in a gender-neutral manner that disguises the real nature of sexual harassment and its particular harm to women as a group. Third, the dignitary paradigm of sexual harassment is analyzed in other cases in moralistic and patriarchal terms that associate dignity with honor and link the harm of sexual harassment to Victorian perceptions of women's honor instead of modern perceptions of human dignity. Women are then stereotyped as fragile, sexually pure, and in need of special protection; the very exposure of women to various sexual behaviors is presented as the central wrong of sexual harassment. Fourth and finally, courts have focused exclusively on the 'sexual' aspect of sexual harassment, thereby legitimating

114. The Supreme Court of Israel is an appellate court as well as the High Court of Justice. As an appellate court, the supreme court considers cases (both criminal and civil) on judgments and other decisions of the district courts. It also considers appeals on judicial and quasi-judicial decisions such as disciplinary rulings.

115. While specifically identifying and analyzing the leading cases that have played a significant role in shaping current discourse on sexual harassment, this study purposely refrained from focusing on the tip of the litigation pyramid and examined the entire body of sexual harassment caselaw in an effort to portray a very broad and comprehensive picture.

116. Of the 222 reported court opinions between March 1998 and September 2006 that were analyzed as part of this study, only three involved men as targets of harassment. All other cases involved the subjection of one woman or several women to sexually harassing behaviors, and in most of them the harassment occurred in the context of clear power differences along gender lines. See supra notes 2 , 113-114 and accompanying text. 
other forms of sex-based harassment that do not involve conduct of a sexual nature. These last two themes usually work in conjunction to reinforce the moralistic interpretation of the wrong of sexual harassment by creating a normative link between 'sex' and the violation of women's honor. These four themes, originally established in the two key decisions of the Israeli Supreme Court, Ben-Asher and Galili, were further developed in subsequent cases. BenAsher articulated the first, second, and fourth themes, and Galili supplemented this framework of analysis with the third moralistic and patriarchal theme.

\section{A. The Supreme Court of Israel}

\section{Four Conceptuai Frames of Reference in Ben-Asher and Galili}

The first explicit judicial reference to the Prevention of Sexual Harassment Law appeared in Israel $v$. Ben-Asher, ${ }^{117}$ a supreme court case involving a disciplinary procedure against a college professor who sexually harassed one of his female students. Though technically decided on the basis of the pre-1998 law, ${ }^{118}$ the court's opinion in Ben-Asher not only mentioned the pending legislation, but also drew upon its theoretical underpinnings and its concrete definitions of sexual harassment. Furthermore, the comprehensive opinion upholding the plaintiff's claim outlined the basic judicial themes of analysis for the new legislation.

Demonstrating the first theme, the court's decision to pay attention to the harm against dignity marginalized the discriminatory aspect of the crime. The court presented sexual harassment as an offense against human dignity, and only in certain cases as a form of discrimination. ${ }^{119}$ Instead of integrating the concepts of equality and dignity, as the feminists who initiated this combined definition of sexual harassment intended, the court created a dichotomized understanding of the phenomenon, one that prioritized dignity over equality in terms of the centrally relevant definition of the injury caused by sexual harassment. While still mentioning gender equality ${ }^{120}$ a reference that is completely neglected in more recent cases-the Ben-Asher court presented the discriminatory harm of sexual harassment as lying at the margins of this social practice. Specifically, the court noted that "[s]exual harassment injures the person, invariably the person's dignity, and sometimes other rights, such as the right to equality or the right to work...."121 Further on the court declared, "Indeed, in many cases sexual harassment and the ensuing impairment of the working conditions can be viewed as a form of sexual discrimination. But

117. CSA 6713/96 Israel v. Ben-Asher [1998] IsrSC 52(1) 650.

118. The opinion in this case was issued one day before the law's enactment.

119. CSA 6713/96 Israel v. Ben-Asher [1998] IsrSC 52(1) 650, 662.

120. Id. at 669 .

121. Id. at 662 . 
sexual harassment is a distinct phenomenon .... and viewing it solely as a form of discrimination blurs the uniqueness of this phenomenon." 122 The court concluded by stating that, having surveyed the law concerning sexual harassment in Israel and in various other countries, "[i]t is widely accepted in Israel, as in other countries, that sexual harassment, aside from its potential material damage, offends against human dignity."

The court's opinion further undermined the significance of the group-based aspects of sexual harassment and the relationship between this social practice and gender inequality by attributing the problem primarily to "social behavior" in a way that almost defends sexual harassment as a natural phenomenon:

Most of the victims of sexual harassment are women... What is the reason for the relative frequency of sexual harassment of women by men? The obvious explanation is that, to a large extent, it expresses the common view regarding differences in the acceptable behavior of men and women in society. An additional explanation is that sexual harassment is, inter alia, a manifestation of the lower status of women in society, notably in employment. According to this explanation, sexual harassment, as well as being a personal offense, also offends against the principle of sexual equality. ${ }^{124}$

This paragraph contains the opinion's most specific reference to the connection between sexual harassment and the lower status of women in society. Nevertheless, even this reference was articulated in a manner that undermines its significance for the analysis of sexual harassment. The sexual harassment of women by men was presented as something most certainly resulting from the fact that men simply behave differently from women. The feminist claim linking sexual harassment to the lower status of women in society was referred to as an additional rather than primary explanation for the problem. This analysis marginalized even further the role of equality, presenting gender inequality as a possible, rather than as a definite, aspect of this phenomenon.

Ben-Asher also demonstrates the second theme, in which an excessive focus on the dignitary harm of harassment and its characterization in genderneutral language leads to the gradual individualization of sexual harassment, overlooking group harm caused by sexual harassment. Despite the fact that Ben-Asher dealt with a typical incident of sexual harassment in terms of its gendered dynamics, the court avoided any substantive account of the gendered significance of the case. Using terminology such as "the harassing person," "the person being harassed" and the "individual dignitary harm"125 to describe the case, the opinion disguised the fact that it was actually about a man in a position of power who demanded sexual favors from a female student who was 
under his authority. Though the court acknowledged that "[s]tudies have shown that, most commonly, sexual harassment is done by a man to a woman," insight was rendered almost meaningless by the lack of discussion of its relevance to the specific case. In summarizing the general nature of sexual harassment, Justice Zamir explained, "Sexual harassment may be done by a woman to a man, and sometimes between members of the same sex .... The common denominator of all forms of sexual harassment is a behavior of a sexual nature by one person which may offend the dignity of another person." 127

Employing genderless and neutral/individual rhetoric, the court presented the group-based understanding of sexual harassment as insignificant, adding:

Sexual harassment crosses the boundary of free behavior, because free behavior necessitates free will on both sides. Hence, sexual harassment is always, in any social setting and anywhere reprehensible. It is reprehensible because it is forced by one individual upon another against his will in the sphere of sex, which by its nature is reserved, above all other spheres, to mutual will. It is also reprehensible because it confuses different categories - it treats an individual according to the individual's sex in an offensive way, when the individual should be treated according to his function or level of achievements in the workplace or in the learning institution. It therefore offends not only the principle of sex-based equality, but also the person's dignity." 128

Here as well the court repeatedly referred to sexual harassment in neutral/individual terms, characterizing it as an act of sexual nature targeting any "person" on an individual basis. Though the court did eventually mention that sexual harassment can also violate the principle of sex-based equality, this mention did not lead the decision toward a more complex understanding of the group-based aspects of the phenomenon. Instead, the role of gender equality in defining sexual harassment remained unclear, while the individual, dignitybased aspects of the phenomenon were greatly emphasized and elaborated.

The third element characterizing the basic understanding of harassment that came to the fore in Ben-Asher was the identification of sexual harassment exclusively as behavior of a sexual nature. Other gender-based forms of hostility or abuse towards working women (or men) that are not sexual in content but that still play a significant role in preserving the workplace as a male-dominated domain were categorically excluded from the formal definition of sexual harassment. ${ }^{129}$ Having given several examples of behaviors that might

126. Id. at 662 (emphasis added).

127. Id. at 662 (emphasis added).

128. Id. at 681 (emphasis added).

129. The most comprehensive discussion of the nature of gender-based forms of harassment and the distinction between such forms of behavior and sexuality-based harassment can be found in Vicki Schultz's seminal work. Schultz has argued that much of the gender-based hostility and abuse that women (and some men) endure at work is neither driven by the desire for sexual relations nor is it even sexual in nature. Instead, many forms of harassment are actions designed to maintain work-particularly 
constitute sexual harassment, such as "talk suggestive of courtship"130 and "requests or suggestions of a sexual nature," 131 Justice Zamir concluded that "behavior does not constitute sexual harassment unless it is, by definition, of a sexual nature. Thus, a particular behavior will not be considered sexual harassment, even if it is harassing, if it is not of a sexual nature or is [not] expressed in matters associated with sex."132 Moreover, the court held that the central issue with which the courts must contend, for future application of the Prevention of Sexual Harassment Law was "[w]hether a behavior of a sexual nature crosses the boundary between the permitted and the prohibited area."133

As the first supreme court case that addressed the new legislation, BenAsher became the guiding precedent for assessing claims of sexual harassment. Frequently cited in later opinions, ${ }^{134}$ Ben-Asher's three main themes have become standard in the judicial discourse on this issue.

A fourth theme, incorporating moralistic, and at times patriarchal, content in judicial analyses has since emerged. Instead of describing the dignitary harm of sexual harassment in neutral/individual terms, the court diverted the legal discussion of sexual harassment's harm to a new path in which the breach of women's honor became the primary wrong of the phenomenon.

The court engaged in this heavily moralistic-patriarchal discourse on sexual harassment in Galili. ${ }^{135}$ The case dealt with the promotion of a senior military officer, Galili, who conducted an intimate sexual relationship with a

the more highly rewarded lines of work-as a bastion of masculine competence and authority. The forms of such harassment are wide-ranging. They include denigrating women's performance or ability to master the job; engaging in deliberate work sabotage; assigning women sex-stereotyped service tasks that lie outside their job descriptions (such as serving coffee); and withholding training, information, or opportunities to learn to do their jobs well. These forms of harassment are gender-based because they play a significant role in preserving job segregation by constructing gender-based differences in work competence. Schultz concludes that the problem of sexual harassment has to be re-conceptualized broadly enough to include all forms of gender-based harassment and not only male-female sexual advances. Vicki Schultz, Reconceptualizing Sexual Harassment, 107 YALE L.J. 1683 (1998).

130. CSA $6713 / 96$ Israel v. Ben-Asher [1998] IsrSC 52(1) 650, 662.

131. Id.

132. Id. at 682 .

133. Id. at 688 .

134. For supreme court cases that cite Ben-Asher, see CertCrA 8059/06 John Doe v. Israel [2006] (unreported case); HCJ 6840/01 Feltzman v. Chief of Staff [2005] (unreported case); CSA 2203/05 Madar v. Civil Serv. Comm'n [2005] (unreported case); CSA 4790/04 Israel v. Ben-Chaim [2005] Pador 05(31) 557; CSA 6920/03 Cohen v. Israel [2004] IsrSC 58(3) 655; HCJ 1435/03 Jane Doe v. Disciplinary Ct. for Gov't Employees in Haifa [2003] IsrSC 58(1) 529; CSA 882/03 Ben-David v. Civil Serv. Comm'n [2003] Tak-Al 2003(2) 3276; CSA 11025/02, 65/03 Eisner v. Israel [2003] IsrSC 57(5) 541; CSA 7113, 7233/02 Israel v. Levy [2003] IsrSC 57(3) 817; CSA 1599/03 Tapiro v. Civil Serv. Comm'n [2003] IsrSC 58(2) 125; CSA 10088/02 Batzon v. Israel [2003] Tak-Al 2003(1) 1884; CSA 6737/02 Israel v. Zaken [2003] IsrSC 57(2) 312; CSA 5771/01 Podlovsky v. Civil Serv. Comm'r [2001] IsrSC 56(1) 463; CSA 1928/00 Israel v. Baruchin [2000] IsrSC 54(3) 694; HCJ 1284/99 Jane Doe v. Chief of Staff [1999] IsrSC 53(2) 62. For a selection of lower court opinions that cite Ben-Asher, see CrimC (PT) 6862/04 Israel v. Yulzari [2006] (unreported case); CrimC (PT) 1222/02 Israel v. Daka [2006] (unreported case); Crim (Nz) 1161/06 Zayad v. Israel [2006] (unreported case); Crim (Jer) $9116 / 05$ Shitrit v. Israel [2005] (unreported case); Crim (Hi) 2596/02 Israel v. Malka [2002] (unreported case); Crim (TA) $71159 / 01$ Israel v. Dahan [2002] (unreported case).

135. HCJ 1284/99 Jane Doe v. IDF Commander (Galili) [1999] IsrSC 53(2) 62. 
young female soldier who served as his secretary. The woman, who later revealed that she was forced into this sexual relationship, petitioned the supreme court and demanded that the officer's pending promotion to the rank of general be halted. The court accepted her petition and ordered the military to refrain from promoting the officer to a higher rank. Written after the 1998 legislation passed, Galili-like Ben Asher-dealt with incidents that occurred before the enactment of the new law. Yet both the complainant and the military referred to the alleged incidents as a form of sexual harassment and pointed to the new legislation that was already in place as signifying a new era in Israeli society's condemnation of this phenomenon. ${ }^{136}$ The court similarly focused the discussion on the sexual harassment of women in the military, and emphasized the significance of the Prevention of Sexual Harassment Law in this context. ${ }^{137}$

In rationalizing and defending its decision prohibiting Galili's promotion, the court relied excessively on moral grounds. Analyzing Galili's behavior within the framework of the general prohibition against sexual harassment anchored in the new legislation, ${ }^{138}$ the court determined that the sexual harassment of women in the military constitutes a moral harm. The court stated that, in addition to its military skills, the power of the Israel Defense Forces ["IDF"] derives from its "moral strength."139 Therefore, an appropriate ruling regarding Brigadier General Galili had to take into account, inter alia, "the utmost importance of preserving morality in the IDF . . and the necessity of strengthening the public's trust in the IDF not only as an efficient body professionally speaking, but as a body of credibility, [and] high moral standards in general ...." 140 The officer, whom the court noted was "married at the time and the father of three," 141 was condemned by the court for "a grave moral stain" "142 upon his character, due to his "obnoxious and immoral conduct." 143 Consequently, the court concluded that the disciplinary measures already taken against him by the military authorities were insufficient "to guarantee purifying the atmosphere." "44 Justice Turkel, who wrote a concurring opinion, repeatedly referred to the notions of "purity" and "morality" when analyzing the incident and its harms. He defined the respondent's actions as "profoundly reprehensible from the moral viewpoint," $" 145$ adding that:

136. Id. at 67-68.

137. Id. at 70-72.

138. After citing a statement from Ben-Asher on the severity of sexual harassment, the Galili court added, "Lately this view [of severity] was given additional force in the Prevention of Sexual Harassment Law-1998, that established sexual harassment as a special offense when it occurs in circumstances of abuse of authority, inter alia in the framework of the military service ..." Id. at 72.

139. Id. at 69 (emphasis added).

140. Id. (emphasis added).

141. Id. at 66 .

142. $I d$. at 68 (emphasis added).

143. Id. at 63 (emphasis added).

144. Id. at 73 .

145. Id at 78 . 
It was about acts such as these that the Bible spoke in reference to the Israelite armies: "When you go out as a troop against your enemy, be on your guard against anything untoward.... Since the Lord your God moves about in your camp to protect you and to deliver your enemies to you, let your camp be holy"... and let our camp be pure. $^{146}$

The words "pure" and "moral" occur, then, numerous times in various forms throughout the Galili majority and concurring opinions. ${ }^{147}$ Moreover, when the court discussed the harms of sexual harassment in the military in reference to the particular plaintiff, and women soldiers in general, the moral dissection of the behavior was compounded by paternalistic language. Referring to the plaintiff as "an inexperienced young woman soldier," 148 the court explained that the officer's behavior violated men's duty to protect women:

[T] he duty of loyalty that the commander in particular, and the army as an institution, owe female recruits, their families and society in general ... encompasses the expectation from every commander carefully to watch over the precious pledge entrusted to him-namely, the human resource, and in the present case, the woman soldier. ${ }^{149}$

By articulating the wrong in terms of its violation of a special protective duty towards women as a group, the court diverted the discussion of sexual harassment to a new path. In contrast to Ben-Asher's individual and genderneutral formulation of the dignitary harm of sexual harassment, Galili was very specific about the gendered context. It was no longer a genderless "person" who was harassed, but rather women as a group. Yet this diversion added an even more troubling aspect to the discussion. While Ben-Asher replaced gender equality with dignity and redefined the harm of sexual harassment in almost solely dignitary terms, Galili provided a patriarchal account of sexual harassment that in fact contradicted and undermined basic notions of gender equality. The court went on to state:

The public which entrusts its daughters to the army must believe that the IDF and its commanders will do all they can to ensure the welfare of the woman soldier and guard her physical and mental well-being. The woman soldier must know that the IDF is a safe place in which to serve. $^{150}$

146. Id. (emphasis added)

147. Justice Strassberg-Cohen also stressed the need to strengthen the image of the military as an institute of "high morality," and further explained that the strength of the military derives from its "moral strength." Id. at 69. Justice Tirkel in his concurring opinion explained that he wished to add something "on morality and values," and determined that the consent of the plaintiff "does not purify" the deeds of the respondents. $I d$. at 77-78.

148. Id. at 70 .

149. Id. (emphasis added).

150. Id. at 73 . 
In the view of the court, the central harm of sexual harassment was restricted to paternalistic considerations designed to accommodate women's special need for protection. As a result, the prevention of sexual harassment was recharacterized as a moral necessity related to women's vulnerability rather than to women's equal rights.

The fact that Galili not only excluded gender equality from the relevant discourse on sexual harassment in the military, but also provided an account that subverts basic notions of gender equality, is particularly troubling since it initiated a more general discussion of sexual harassment in the military. While the complainant focused mostly on the manner in which the officer's behavior wronged her, ${ }^{151}$ the court justified its final decision on more general grounds relating to the significance of sexual harassment in the military and its particular harm. Under those circumstances, the discursive framework adopted by the court had broader implications regarding the proper understanding of sexual harassment in general and in the military in particular.

Given the IDF's male-dominated hierarchical structure, ${ }^{152}$ it is very important to highlight the connection between its built-in gender inequality and the prevalence of sexual harassment against women soldiers. Israel is the only western democracy with compulsory conscription for both men and women. Despite this formal egalitarian draft policy, the Israeli army is still an institution where manhood, exclusively identified with power and authority, is the norm. ${ }^{153}$ Unlike men, women are easily exempted from military service on grounds of marriage, pregnancy, motherhood, religious beliefs, or conscientious objection. ${ }^{154}$ Women serve a shorter term than men, and have been traditionally excluded from combat roles. In recent years some combat positions were redefined as gender integrated, but the presence of women in

151. Id. at 68

152. Noya Rimalt, Women in the Sphere of Masculinity: The Double-Edged Sword of Women's Integration in the Military, 14 DUKE J. GENDER L. \& POL'Y 1097 (2007).

153. See id.

154. See Defence Service Law [Consolidated Version] 5746-1986, 39 LSI 112 (1985-86) $\S \S 39-40$ (Isr.). For the historical background of those legal exemptions, see Noya Rimalt, Equality with a Vengeance: Female Conscientious Objectors in Pursuit of a Voice and Substantive Gender Equality, 16 COLUM. J. GENDER \& L. 97 (2007). Similar exemptions from regular and reserve military duty have not been formulated for men. The only legal basis for exemption of this kind is found in another section of the Defense Service Law of 1986, which grants the Minister of Defense general discretion to exempt "a person of military age" from the duty to perform military service "for reasons connected with the requirements of education, security, settlement or the national economy or for family or other reasons." Defense Service Law $\$ 36$ (emphasis added). The relevant provisions of section 36 read:

The Minister of Defence may, by order, if he sees fit to do so for reasons connected with the size of the regular forces or reserve forces of the Israel Defence Forces or for reasons connected with education, security, settlement or the national economy or for family or other reasons

(1) exempt a person of military age from the duty of regular service or reduce the period of his service;

(2) exempt a person of military age from the duty of reserve service for a specific period or absolutely.

Defense Service Law $\S 36$. 
those roles is still marginal, ${ }^{155}$ and the military remains highly segregated along gender lines. Being a secretary in the military continues to be a predominantly female experience, with one in every five women soldiers serving in this traditionally female job. In contrast, commanding high-ranking officers are still primarily male. In 2006, ninety-seven percent of the highest decision-making positions in the military were filled by men. ${ }^{156}$ In light of this reality, the gendered significance of Galili's behavior becomes more apparent. The woman who filed the complaint against Brigadier Nir Galili served as his secretary to fulfill part of her compulsory military service. The presence of women soldiers who are subordinate to high ranking male officers is therefore not unusual or incidental to the Israeli military. Recent data regarding the prevalence of sexual harassment in the military indicates that the military is one of the most hostile and demeaning places for women in the public sphere in terms of the intensity of sexual harassment. ${ }^{157}$ A 2004 survey conducted by the IDF itself revealed that when women soldiers were asked about specific examples of harassment such as humiliating sexual jokes and stories, seventy-six percent of female officers and sixty-six percent of regular female soldiers reported that they were subjected at least once to hostile environment sexual harassment. ${ }^{158}$ Similarly high figures were discovered with regard to sexual innuendo. ${ }^{159}$ Moreover, the fact that a few women have managed to cross gender barriers in the military in recent years and have volunteered for combat roles has not changed the intensity of harassment they experience. ${ }^{160}$ Sexual harassment is a predominant experience of many women soldiers, including those few who serve in more "masculine" roles. ${ }^{161}$ In sum, sexual harassment constitutes a powerful example of a patriarchal behavior that plays a part in the socialization process of young male soldiers and contributes to the structural maintenance of military service as a gender-biased system. Sexual harassment affects mostly women soldiers ${ }^{162}$

155. Rimalt, supra note 152 , at 1113.

156. Id. at 1113-14.

157. Sarit amram Katz, The SeXual Harassment of Women in the IDF: Research Among FEMALE SOLDIERS AND OFFICERS IN COMPULSORY SERVICE (2d ed. 2005), available at http://www.aka.idf.il/SIP_STORAGE/files/ 2/47822.pdf.

158. Id. at 26.

159. Id. at 26 .

160. Id.

161. For a detailed analysis of the nature and significance of those findings, see Rimalt, supra note 152; and Rimalt, supra note 52.

162. A 2001 survey of IDF soldiers reflect that one in five women in the IDF had been sexually harassed. Moreover, the military's own findings indicate that most of the soldiers who are subject to sexual harassment do not file an official complaint. Therefore the actual prevalence of the phenomenon is much higher than the number of official complaints that are filed each year. KATZ, supra note 157; Gideon Alon, A 78\% Rise in Complaints of Sexual Harassment in the IDF in 2003, HAARETZ, available at http:/Www.haaretz.co.il/hasite/pages/ShArtPE.jhtml?itemNo=428826\&contrassID=2\&subContrassID $=21 \&$ sbSubContrassID=0 (last visited Nov. 29, 2007). In 1999, 436 soldiers filed official complaints about sexual harassment: 9 men and 427 women. In 2002, the numbers were 209 women and 8 men, and in 2003, 386 women and 17 men. The IDF: A 78\% Rise in Complaints of Sexual Harassment, YNET (Jan. 24, 2005), available at http://www.ynet.co.il/articles/0,7340,L-2917767,00.html. See also Protocol 
and serves as an effective tool for reminding Israeli women of their "proper place" in society, perpetuating their image as sexual objects and hindering their efforts to gain authority and power within the military.

As the first supreme court case aspiring to provide a general framework for the analysis of sexual harassment in the military after the enactment of the new law, Galili could have assessed the connection between this case and the broader reality of gender inequality in the military. Because the court neglected to assess this issue, the decision disguised the broader gendered picture within which the severity of the Galili behavior should have been evaluated. The court's decision in Galili, which sought to outline a general framework for the discussion of sexual harassment in the military, therefore failed on two significant accounts. First, by leaving the principle of gender equality out of the discussion, it ignored an important concept for the analysis and understanding of this social practice. Second, by supplementing the exclusion of equality discourse with a conceptual reversal of the meaning of sexual harassment and its injurious effect on women, it defined sexual harassment in anti-feminist terms. Ben-Asher began the shift away from the original feminist rationale for the law, by imbuing the concept of human dignity with gender-neutral, individual content. Galili then added a further normative shift, depriving the concept of human dignity of any liberal and egalitarian significance and replacing it with moralistic and patriarchal notions of women's honor that resonated with the old tradition of protecting women's honor against seducers. Between Ben-Asher and Galili the dignitary harm of sexual harassment was defined in two alternative manners - each problematic in its own way. BenAsher conceptualized the dignitary harm of sexual harassment as a genderless/individual harm that, when inflicted on a random victim, violates this person's human dignity. In Galili, on the other hand, the dignitary harm of harassment centered on a Victorian perception of women's honor and connected sexual harassment to gendered codes of sexual purity. Neither opinion linked the prevention of sexual harassment to society's commitment to the promotion of gender equality and women's rights. Yet while Ben-Asher still employed a rights discourse to explain the harm of harassment, Galili diverted the focus to a patriarchal path, thereby promoting an understanding of sexual harassment that is in fact demeaning to women.

Galili, like Ben-Asher, became an important source for reference in the judicial discussion and analysis of sexual harassment. ${ }^{163}$ As will be discussed in

\footnotetext{
of the 47th Meeting of the 15th Knesset, Nov. 15, 1999 (on file with author) (discussing sexual harassment of male soldiers).

163. See, e.g., HCJ 6840/01 Feltzman v. Chief of Staff. [2005] (unreported case); CSA 4790/04 Israel v. Ben-Chaim [2005] Pador 05(31) 557; CSA 1599/03 Tapiro v. Civil Serv, Comm'n [2003] IsrSC 58(2) 125; HCJ 4869/01 Jane Doe v. Military Advocate General [2002] IsrSC 56(3) 944; CA 1928/00 Israel v. Baruchin [2000] IsrSC 54(3) 694; CrimA (Hi) 2596/02 Israel v. Malka [2002] (unreported case); CrimS (TA) 1037/01 Israel v. Machluf [2002] Tak-Mach 2002(1) 2507; CrimC (KS) 1342/00 Israel v. Dahan [2003] (unreported case).
} 
the next Section, alongside the analytic themes that were established in BenAsher, the moralistic and patriarchal discourse has occupied a strong and explicit place in court opinions after Galili, thus further promoting the antiequality interpretation of the dignitary harm of sexual harassment.

\section{Subsequent Supreme Court Cases Further Establish and Develop the Four Frames of Reference}

Opinions handed down by the Supreme Court of Israel after Ben-Asher and Galili illustrate and build upon the four central frames of reference that took shape in those cases. Because the supreme court serves as an appellate court for disciplinary procedures against state employees, the vast majority of supreme court cases dealing with the Prevention of Sexual Harassment Law concern sexually harassing behaviors of state employees. ${ }^{164}$ Israel v. Baruchin, for example, concerned a senior official in the Ministry of Defense who, over a period of three years, sexually harassed four women soldiers serving under his supervision. ${ }^{165}$ Some female conscripts are assigned to various administrative and secretarial civilian jobs in government offices that deal with security issues, such as the Ministry of Defense or the Prime Minister's office. The result is that state employees often serve as those women's direct supervisors; Baruchin provides a typical example of this problematic working relationship. On its face, the systematic pattern of harassment against several women in the same workplace and in the context of clear power differences along gender lines could have evoked a substantive discussion of sexual harassment's gendered significance and harm. However, as in Ben-Asher and Galili, the court largely avoided the link between sexual harassment and gender inequality. With the exception of a quote from the explanatory note to the Prevention of Sexual Harassment Law, which included a reference to the principle of sex-based equality, ${ }^{166}$ the court diverted the judicial analysis of the dignitary harm of sexual harassment away from equality and toward the two alternative conceptual paths established by Ben-Asher and Galili.

164. CSA 6713/96 Israel v. Ben-Asher [1998] IsrSC 52(1) 650; CSA 2203/05 Madar v. Civil Serv. Comm'n [2005] (unreported case); CSA 4790/04 Israel v. Ben-Chaim [2005] Pador 05(31) 557; CSA 6920/03 Cohen v. Israel [2004] IsrSC 58(3) 655; HCJ 1435/03 Jane Doe v. Disciplinary Court for Gov't Employees [2003] IsrSC 58(1) 529; CSA 882/03 Ben-David v. Civil Serv. Comm'r [2003] Tak-Al 2003(2) 3276; CSA 11025/02, 65/03 Eisner v. Israel [2003] IsrSC 57(5) 541; CSA 7113, 7233/02 Israel v. Levy [2003] IsrSC 57(3) 817; CSA 1599/03 Tapiro v. Civil Serv. Comm'n [2003] IsrSC 58(2) 125; CSA 10088/02 Bazon v. Israel [2003] Tak-Al 2003(1) 1884; CSA 6737/02 Israel v. Zaken [2003] IsrSC 57(2) 312; CSA 5771/01 Podlovsky v. Civil Serv. Comm'r [2001] IsrSC 56(1) 463; CSA 1928/00 Israel v. Baruchin [2000] IsrSC 54(3) 694.

165. CSA 1928/00 Israel v. Baruchin [2000] IsrSC 54(3) 694. Baruchin was indicted and convicted for addressing sexual remarks to those female soldiers such as "what a nice ass you have" or "what a sexy body." He also forcefully hugged and kissed those women on several occasions. Id. at 699.

166. Id. at 707 . 
Most of the decision employs a gender-neutral/individual rhetoric, repeatedly referring to sexual harassment as an offense against the dignity of a genderless victim. For example, in order to stress the judiciary's commitment to combating sexual harassment and clarifying the nature of this social practice, Justice Zamir, the sole presiding judge in this case, ${ }^{167}$ quoted from an earlier supreme court decision that dealt with sexual exploitation in the workplace:

It is an intolerable phenomenon, which is unfortunately widespread, that employers and people in positions of power exploit their authority over their subordinates for their own sexual benefit. The subordinates' dependence on those people causes them real distress, and they often submit and acquiesce in such conduct, which is not only reprehensible and in poor taste, but humiliates the person that is subjected to it and gravely offends this person's dignity and privacy. ${ }^{168}$

Further on, Justice Zamir reinforced his portrayal of sexual harassment as affecting genderless individuals with a quote from his own decision in BenAsher: "Nowadays, it is generally agreed ... that sexual harassment, in addition to possibly causing material damage, offends against the person's dignity."169 Moreover, although the court formally acknowledged that the case involved the harassment of several women, this did not lead to a recognition of the significance of this gendered aspect of the case and did not change the court's gender-neutral frame of analysis. The particular severity of the case was explained by reference to the fact that several "persons" had been harassed such that the cumulative individual injury was greater:

Even if each individual case of such harassment [of a single woman], in the form of a hug or a kiss or a sexual remark, is not a grave incident, the combination of incidents, one after the other, makes the sexual harassment a gross and particularly humiliating behavior: There is nothing in it of emotional closeness and mental affection, but utterly demeans the person as an instrument of sexual stimulation and satisfaction. ${ }^{170}$

Theoretically speaking, it is entirely true, of course, that the sexual harassment of every person is a degrading practice. However, the court in Baruchin was not discussing sexual harassment in theory, but was referring to a specific case with clearly gendered characteristics. This case was also not an

167. Disciplinary appeals are heard and decided by a sole presiding justice of the supreme court, who usually hears all of those appeals brought during a certain period of time. Therefore, most of the court opinions in this area were delivered by two justices: Justice Zamir, who decided these cases until his retirement in 2001; and later by Justice Beinish, who was the senior female justice of the supreme court and who is now the Chief Justice of the Supreme Court of Israel. While other justices have contributed to the development of supreme court sexual harassment caselaw in cases such as Galili, Zamir and Beinish have played the most significant role in this regard.

168. CSA 1928/00 Israel v. Baruchin [2000] IsrSC 54(3) 694, 707 (emphasis added) (citing CrimA 2695/93 Shiri v. Israel [1993] (unreported case)).

169. Id. (citation omitted) (emphasis added).

170. Id. at 712 (emphasis added). 
isolated one. It followed two other supreme court sexual harassment cases with similarly gendered characteristics, Ben-Asher and Galili. The pattern of harassment that was evident in all three cases confirmed arguments that were raised during the legislative deliberation over the Prevention of Sexual Harassment Law regarding the ways in which sexual harassment is especially harmful to women. ${ }^{171}$ Baruchin's systematic sexual harassment of several women in the same workplace was especially serious not just because of the cumulative individual injury, but also because of its wider implications for the status of women as a group. It was not just an offense against "a person," and another "person," and another "person," but an offense against women as such-an important distinction that the court failed to make. Additionally, even as an individual injury, the sexual harassment of a woman goes beyond humiliation; it affects her autonomy in the workplace, restricts her opportunities, and undermines her professional status. ${ }^{172}$ Limiting the discussion of injury not only to a genderless victim but also to the individual, humiliating features of sexual harassment obscures and belittles much of its harm.

Toward the end of the Baruchin decision, the court adopted the Galili frame of reference, switching away from a gender-neutral/individual analysis of the dignitary harm of harassment to a moralistic and patriarchal argument that some circumstances of sexual harassment are worse than others because of society's special protective duties towards certain groups of women. Following various citations from Galili regarding society's obligation to guard and protect its young daughters in the military, ${ }^{173}$ the court explained the particular severity of the sexual harassment of female soldiers in the following manner:

The female soldier might be seen by the male worker in the Ministry [of Defense] as an easy prey for sexual satisfaction. Such a worker has to know that sexual harassment of a female soldier is graver than sexual harassment of a woman civilian: it undermines the [general] attitude of trust and appreciation towards the military, not only on the part of the woman soldier and her family but also on the part of the

171. See supra note 102 and accompanying text.

172. This aspect of harm associated with sexual harassment is identified by Kathryn Abrams as one important aspect that courts should consider in assessing sexual harassment cases. Specifically, Abrams identifies four factors relating to the nature, harm, and effect of sexual harassment that a reasonable trier of facts should be familiar with in order to assess the pervasiveness of sexual harassment in a particular case: (1) sexual harassment interacts with other barriers in the workplace that marginalize women; (2) women associate sexual harassment with "intimidation, objectification, and devaluation" when it occurs in the workplace; (3) sexual harassment "produce[s] a range of effects on the work lives" of its targets, effects that can alter their conditions of employment, their ability to chart a desired professional path, and their self esteem; and (4) the target's response at the time of the harassment is rarely a good indicator of whether the behavior was problematic or even whether the target felt distressed by the conduct. Kathryn Abrams, The Reasonable Woman: Sense and Sensibility in Sexual Harassment Law, DISSENT, Winter 1995, at 48, 52-54. For further discussion of the gendered harm of sexual harassment, see also Abrams, The New Jurisprudence of Sexual Harassment, supra note 44, at 1184-88, 1218-20.

173. CSA 1928/00 Israel v. Baruchin [2000] IsrSC 54(3) at 712-13. 
wide general public and it [therefore] has the flavor of a breach of trust. $^{1 / 4}$

Thus, when finally attributing significance to the gender of Baruchin's victims, the court reduced the discussion to an assertion that young women soldiers are worthy of greater protection against harassment in order to preserve public trust in the military. Just as in Galili, it was women's vulnerability rather than women's basic rights that captured the discussion once the court integrated gender into its analysis.

Baruchin's line of reasoning, which conceptualizes the dignitary harm of sexual harassment either in moralistic terms deriving from patriarchal perceptions of women or in gender-neutral and individual terms, is evident in later supreme court cases, as are the two other themes of analysis. In Podlovsky $v$. Civil Service Commissioner, ${ }^{175}$ the court dealt again with a case that involved an obviously gendered pattern of harassment. Podlovsky, who served at the time as the head of a governmental advisory bureau for veterans, pretended to be a sexologist and a psychologist to the women soldiers under his command. He then urged them to discuss their sex lives with him, made sexual comments to them, told them dirty jokes, harassed them physically, and created a sexual and hostile environment in the office. Podlovsky, like Baruchin before it, provides a typical example of the problematic effects that can arise within a working relationship where state employees directly supervise women conscripts. In assessing the appropriate disciplinary measures to be taken against the harasser, Justice Beinish stated:

Blatant sexual expressions that offend the dignity of women, especially when uttered before young women soldiers who have to contend with a new world, facing the power and authority of a command hierarchy, are a grave offense .... The creation of a setting and conditions that encouraged the women soldiers to discuss with him their sex life, produced in the office a coarse and vulgar atmosphere that offended against the human dignity of the women soldiers in his company. ${ }^{176}$

Throughout her opinion, Justice Beinish alternately referred to the women soldiers who had been harassed as "girls" "177 and as "young girls," "178 thereby conflating, as in Galili, the severity of the offense with the young age of the victims, infantilizing the women and presenting them as particularly vulnerable and in need of special protection. Here, too, all considerations of gender equality and the status of women in the military were left out of the court's discussion. Moreover, reemphasizing Ben-Asher's holding regarding the inherently sexual nature of the prohibited harassment under the law, the

174. Id. at 713 .

175. CSA 5771/01 Podlovsky v. Civil Serv. Comm'r [2001] IsrSC 56(1) 463.

176. Id. at 80 .

177. Id. at 477.

178. Id. at 478. 
Podlovsky court connected the defendant's actual acts of harassment, which in this case were overtly sexual, to the fundamental purpose of the Prevention of Sexual Harassment Law. Specifically, the court explained that the law's specific definitions of various forms of sexual harassment "suggest that the legislation sought to define a broad spectrum of cases in which expressions of a sexual nature would be regarded as sexual harassment." $" 179$ This case ultimately centered on the "sex" in harassment and the young age of the harassed women as the primary relevant factors for an assessment of the harmful consequences of the specific incidents of harassment. Combining Galili's patriarchal conceptualization of the dignitary harm of harassment with Ben-Asher's understanding of sexual harassment as involving solely sexual behavior, Podlovsky reinforced the moralistic interpretation of the wrong of sexual harassment by creating a normative link between "sex" and the violation of young women's honor.

Another illustration of the problematic implications of judicial treatment of sexual harassment can be found in Israel v. Levi. ${ }^{180}$ The case, like Baruchin and Podlovsky, concerned a state employee, a senior figure in the Ministry of Defense, who sexually harassed a woman who served in his division, first as a soldier and then as a civilian. ${ }^{181}$ The opinion, delivered again by Justice Beinish, revealed that the harassing incidents took place throughout the entire period of the complainant's employment at the Ministry, and occurred in almost every professional interaction she had with her harassing boss. ${ }^{182}$ In summarizing the relevant events, the court concluded that each time the female soldier tried to perform her professional tasks, her boss diverted the interaction between them to sexual matters, with the woman's sexuality being the main criteria for defining and assessing her performance in the workplace. ${ }^{183}$ When she tried to provide him a report at the end of each night shift, for instance, he made sexual remarks to her, thereby undermining her effort to assert a professional rather than a sexual identity at work. When the female employee could no longer tolerate the continuing acts of harassment and the hostile working environment it created for her, she left her job. What started as an empowering process for a woman soldier who was assigned as part of her compulsory military service to the prestigious, male-dominated Ministry of Defense,${ }^{184}$ and who subsequently won a desirable position in the same office

179. Id. at 473 (emphasis added).

180. CSA 7113, 7233/02 Israel v. Levi [2003] IsrSC 57(3) 817, 823-25.

181. Shachar Levi was originally indicted on three counts of sexual harassment that involved three different women. He was eventually convicted of sexually harassing only one woman. The court determined that his relationship with the first complainant was consensual, and the second complainant failed to show up for hearings. Id. at 817 .

182. Id. at 836 .

183. Id. at 833 .

184. Levi was decided in 2003. In that year, the Ministry of Defense employed 656 employees in managerial positions, only twenty-six percent of whom were women. Moreover, most of these women were at the bottom of the managerial pyramid, occupying the least prestigious management positions. 
after her military service came to an end, culminated in a process of alienation that damaged her professional trajectory and self esteem and caused her to quit her civilian job.

Levi illustrates a common problem: Women who venture into maledominated workplaces are often not welcomed but instead treated as a threat and subjected to sexual harassment that creates a hostile and demeaning work environment for them. In circumstances where this harassment eventually drives the women to quit, the male domination of that workplace is reinforced and gender segregation between careers is further perpetuated. The link between hostile work environment sexual harassment and job segregation on the basis of gender is documented in feminist literature ${ }^{185}$ and has been recognized by a number of American courts. ${ }^{186}$ Hence, for a proper understanding of the gendered significance of the various incidents of harassment that occurred in Levi it is important to recognize that the harassment of the female employee eventually played a role in preserving the masculine image of a traditionally segregated workplace. ${ }^{187}$

Although the court mentioned that the female employee eventually quit her job, the court avoided any further reference to the meaning and possible implications of that fact. Instead, the court focused its discussion of harm on the fact that the female employee was a particularly young and physically weak woman who had suffered several years earlier from anorexia, ${ }^{188}$ explaining: "[Levi] misused his authority on [the complainant]... despite [her] young age ... and in spite of him being aware of her heightened vulnerability because of the illness she struggled with in the past."189 While Levi's harassing behavior forced the complainant to quit her job, exemplifying the relationship between sexual harassment and the exclusion of women from male dominated jobs, when summarizing Levi's wrongdoing, Justice Beinish chose to emphasize over and over again the woman's "heightened vulnerability" and Levi's disregard of this physical weakness:

The sexual remarks of the appellant were directed toward [the complainant and] were repeated over several months. This, despite his senior position as a supervisor and in spite of his being aware of her young age .... What makes it most severe is that the appellant was aware of [the victim's] heightened vulnerability due to the illness she

\footnotetext{
The deputy manager was a man and so were thirteen out of fifteen heads of departments. The third highest ranking job level in the Ministry, that of deputies to the heads of departments, consisted of thirty-eight men and seven women. CIVIL SERVICE COMMISSION, STATE OF ISRAEL, 2003 REPORT OF the DePartment For the PROMOtion AND INTEgration of WOMEn (Ya'akov Berger \& Rivka Shacked eds., 2004).

185. See, e.g., MACKINNON, supra note 68 , at 16; Schultz, supra note 129 , at 1756-61.

186. See Schultz, supra note 129, at 1769-74.

187. See supra note 185 and sources cited therein.

188. Earlier in the opinion, the court explained that the complainant suffered from anorexia at the age of fourteen. CSA 7113, 7233/02 Israel v. Levi [2003] IsrSC 57(3) 817, 834.

189. Id. at 836 (emphasis added).
} 
struggled with in her past, but nevertheless did not refrain from addressing sexual remarks to her. ${ }^{190}$

Ultimately, the gravity of the harasser's behavior was explained as relative to the particular vulnerability of the complainant. He was not disciplined for undermining her professional status and equal opportunity in the workplace, but rather for being insensitive in addressing sexual remarks to a young and physically weak woman. This conclusion blunts the unequivocal message that the court should have issued concerning the gravity of the sexual harassment by a male supervisor of a female employee in a male-dominated workplace. Irrespective of the past illness of the particular victim, the various incidents of harassment clearly constituted gender discrimination. Diverting the focus of the discussion to the victim's specific weakness obscured a crucial gendered harm that was clearly evident in this case; the court also re-characterized the entire case as an unfortunate, almost random, incident relating to a particularly helpless woman who was wronged by being subjected to an improper sexual behavior.

A similar disregard of the relationship between sexual harassment and gender inequality is evident in Zarzar v. Civil Service Commissioner. ${ }^{191}$ The case applied Galili's moralistic frame of reference, in which the exposure of a woman to an expression of sexual desire was perceived as the core of the offense under the Prevention of Sexual Harassment Law, and supplemented this patriarchal conceptualization of the harm of harassment with a natural/biological reference to the harassing behavior itself that further disparaged the significance of this practice and its harm.

For many years, Zarzar had been in charge of the Office of Public Complaints and was a chief investigator at the Ministry of Transport. He was accused and convicted of sexually harassing a woman who came to his office to lodge a complaint against a taxi driver. Zarzar hugged, kissed, and touched the woman's body without her consent. The disciplinary court ${ }^{192}$ ordered his dismissal from the civil service, giving the following rationale, which was cited verbatim by the supreme court in its ruling on the appeal: "Instead of doing his work honestly and investigating the complainant's complaint ... [the accused] made a mockery of his role and gave free rein to his lust, committing acts upon the complainant's body which today are defined as sexual harassment."193 The court's discussion of Zarzar's offense attributed the sexually harassing behavior to his failure to "rein" in his sexual impulses, thereby implicitly portraying the incident as natural, if at times inappropriate. Instead of defining the relevant

190. Id. at 845 .

191. CSA 309/01 Zarzar v. Civil Serv. Comm'r [2001] IsrSC 55(2) 830.

192. In matters relating to disciplinary offenses including sexual harassment state employees are tried before the Disciplinary Court for State Employees. The supreme court serves as an appellate court for those rulings. See supra notes 114, 167 and accompanying text.

193. CSA 309/01 Zarzar v. Civil Serv. Comm'r [2001] IsrSc 55(2) 830, 835. 
incident of harassment as an assertion of power in the context of unequal gender relations, it was portrayed as an act resulting simply from the harasser's human (natural or biological) weakness. ${ }^{194}$ Hence, by presenting sexual harassment as resulting from natural instincts rather than the product of socially constructed choices, the court provided a portrayal of sexual harassment that made it more socially acceptable.

In considering the proper disciplinary measures that should be taken against the harasser, the supreme court noted that:

[The disciplinary court] has come to the conclusion that removing the accused from the civil service demonstrates the principal purpose of disciplinary action- the preservation of the image and moral decency of the public service. ${ }^{195}$

In the supreme court's opinion, which embraced the disciplinary court's entire ruling, Zarzar was punished for "giving free rein to his lust" in the presence of the complainant, thereby injuring "the moral decency" of public service. Hence, the court not only excluded the goal of promoting gender equality from the relevant scope of the Prevention of Sexual Harassment Law-it also tied the law's objective to moralistic considerations that replicate Galili's patriarchal frame of reference. The question of what makes sexual harassment such a grave offense was ultimately resolved again by an implicit reference to sex, morality, and women's honor.

The court further consolidated these themes in the case of Eliezer Hamani ${ }^{196}$ who, prior to retiring, had been a deputy auditor in the Ministry of Religious Affairs. For several years, Hamani subjected a subordinate female employee to acts and expressions of a sexual nature. However, the Disciplinary Court for State Employees decided that those acts did not constitute sexual harassment, because the harasser and the complainant appeared to be in a close relationship during the relevant period, and because the complainant did not resist the defendant's behavior. Therefore, with regard to most of the alleged incidents, Hamani was not convicted of sexual harassment. Instead, the disciplinary court determined that, in his sexual behavior, Hamani, a state employee, undermined the reputation and public image of the civil service, and it was for this offense that he was disciplined. The court did, however, conclude that Hamani deserved to be convicted of sexual harassment in one specific incident, which occurred "in public" when the complainant was speaking with another female employee. According to the court's description of the

194. This natural/biological approach to sexual harassment is not new or unique. Catherine MacKinnon points out that early American cases that rejected sexual harassment claims altogether did so based on the idea that biology cannot be questioned or changed. She further explains: "In the biological view, sexual expression seems presumed to derive from a biological need or genital drive or to be rooted deeply in a natural order that connects biological differences with expressions of mutual attraction." MACKINNON, supra note 68 , at 91 .

195. CSA 309/01 Zarzar v. Civil Serv. Comm'r [2001] IsrSc 55(2) 830, 835 (emphasis added).

196. CSA 2168/01 Hamani v. Civil Serv. Comm'r [2001] IsrSC 55(5) 949. 
occurrence, Hamani "grabbed [the complainant's] breast in his hand and told her he loved it. The complainant slapped away his hand and asked that he stop such acts. The appellant removed his hand from her breast, then touched her genitals through her dress." 197 The disciplinary court determined that this incident was "exceptional and extraordinary even in that close relationship," 198 and therefore deserved the title of sexual harassment.

On appeal, Justice Beinish upheld both parts of the disciplinary court's decision, affirming that the main harm Hamani's actions caused was damage to the image and reputation of the civil service. Justice Beinish noted that:

Behavior in the workplace characterized by remarks of a sexual nature, open acts of a sexual nature, touching, and acts carried out in public and routinely [directed] to a woman employee at her place of work, is a behavior that gives rise to an atmosphere that is inappropriate in the civil service... It got to the point that the man who ran the canteen for years said in his testimony that [it is] "hard to believe that this is the Ministry of Religious Affairs." 199

Neither the disciplinary court nor the supreme court critically examined the power relations between Hamani, a powerful senior official in the Ministry of Religious Affairs, and the subordinate woman employee, nor did they analyze the possible nature and consequences of such harassment. Rather, both courts contented themselves with a discussion of the importance of preserving moral decency in public service. The sole criterion used to identify the single incident defined as sexual harassment was its extreme sexual crudeness, which was described as "exceptional" and "extraordinary." In this context, as in BenAsher, the judicial condemnation of the described behavior focused on its sexual and public nature, leading to the conclusion that the core of the problem was the exposure of the woman to sex.

\section{Recent Developments in Supreme Court Caselaw}

The four frames of analysis adopted by the supreme court regarding sexual harassment repeatedly surface in more recent cases. Moreover, as time goes on, the problematic implications of these frames of analysis have intensified. For example, while in Ben-Asher and other cases such as Baruchin that followed soon after, the principle of gender equality was at least mentioned as marginally relevant to the understanding and analysis of sexual harassment, in current opinions, the judicial discussion of sexual harassment portrays the offense solely in dignitary terms. 
Israel v. Ben-Haim ${ }^{200}$ clearly demonstrates the establishment of an exclusively dignitary paradigm of sexual harassment in contemporary judicial discourse. Ben-Haim, like almost all reported sexual harassment cases that have been heard by the Supreme Court of Israel since the 1998 law was passed, involved a man who abused his authority and sexually harassed a female in the context of clear power differences along gender lines. ${ }^{201}$ In this regard, the case, decided in 2005 , followed a long line of opinions that revealed a similarly gendered pattern of harassment. Serving as a manager with the Postal Service, Ben-Haim demanded sexual favors from a temporary female employee, promising to improve her working terms and conditions in exchange. Nevertheless, when explaining why the Prevention of Sexual Harassment Law specifically prohibits the kind of acts committed by Ben-Haim, Justice Beinish adopted gender-neutral language and excluded gender equality from the relevant framework of analysis. Portraying sexual harassment as a social phenomenon that commonly involved "one person" who imposes his or her will on "another person," she further identified human dignity and autonomy as the central values that the new legislation aimed to protect:

The actions defined in section 3(a) to the law are prohibited because they refer to circumstances in which one person imposes his/her will on another person. These circumstances involve a violation of a person's dignity and autonomy in the context of his/her sexuality. Human dignity and autonomy are therefore the main values that the Prevention of Sexual Harassment Law intends to protect. ${ }^{202}$

Further on in her opinion, Justice Beinish noted that sexual harassment commonly occurs in the context of abuse of authority. ${ }^{203}$ However, she did not mention that, in the vast majority of sexual harassment cases, this abuse of authority has clearly gendered characteristics. She ignored the gendered and group patterns of behavior that connected Ben-Haim to previous supreme court cases. This frame of analysis neutralized and individualized the relevant

200. CSA 4790/04 Israel v. Ben-Chaim [2005] Pador 05(31) 557

201. For supreme court sexual harassment cases that were heard and decided before Ben-Chaim and exemplify the gendered pattern described above, see CSA 6920/03 Cohen v. Israel [2004] IsrSC 58(3) 655; CSA 1599/03 Tapiro v. Civil Serv. Comm'r [2003] IsrSC 58(2) 125; CSA 11025/02, 65/03 Eisner v. Israel [2003] IsrSC 57(5) 541; CSA 7113, 7233/02 Israel v. Levy [2003] IsrSC 57(3) 817; HC 4869/01 Jane Doe v. Military Advocate General [2002] IsrSC 56(3) 944; CSA 8431/01 lsrael v. Danino [2001] IsrSC 56(2) 577; CSA 5771/01 Podlovsky v. Civil Serv. Comm'r [2001] IsrSC 56(1) 463; CSA 1928/00 Israel v. Baruchin [2000] IsrSC 54(3) 694; HC 1284/99 Jane Doe v. Chief of Staff [1999] IsrSC 53(2) 62; CSA 6713/96 Israel v. Ben-Asher [1998] IsrSC 52(1) 650; CSA 2868/04 Shamian v. Civil Serv. Comm'r [2004] Pador 04(8) 764; CSA 882/03 Ben-David v. Civil Serv. Comm'r [2003] Tak-Al 2003(2) 3276; CSA 10088/02 Bazon v. Israel [2003] Tak-Al 2003(1) 1884; HC 6840/01 Feltzman v. Chief of Staff [2005] (unreported case); CSA 2203/05 Madar v. Comm'r of Civil Serv. [2005] (unreported case); CSA 10575/03 Ben-David v. Civil Serv. Comm'r [2004] (unreported case); CSA 10728/02 Asadi v. Civil Serv. Comm'r [2003] (unreported case); CSA 1934/03 Falach v. Civil Serv. Comm'r [2003] (unreported case). The few remaining supreme court cases also involved a male harassing a female, but there was no formal status difference between the two.

202. CSA 4790/04 Israel v. Ben-Chaim [2005] Pador 05(31) 557, at *3.

203. Id. at $* 4$. 
incident of harassment and disassociated its harms from the broader, gendered context in which those harms occurred. As a result, Ben-Haim was found guilty and disciplined only for imposing his will on "another person" in a manner that violated that "person's dignity and autonomy."

Similarly, the court justified Samuel Bazon's dismissal from public service in Israel v. Bazon with gender-neutral rhetoric, rather than by highlighting the particularly severe gendered aspects of his acts. ${ }^{204}$ Bazon, a powerful manager with the Employment Service, sexually harassed a temporary female employee both verbally and physically. Fully aware of his victim's economic hardshipshe was an immigrant, recently widowed, and in dire need of a permanent position - he persuaded her to give him her telephone number, promising to extend her term of employment. Later, he repeatedly harassed her over the phone, intimidating her at home as well as at work. ${ }^{205}$ Summarizing its reasons for choosing a deterrent punishment, the court avoided any reference to the significance and implications of the gendered context of this case, and explained that " $[t]$ he scope of the phenomenon of sexual harassment, and specifically the injury to the dignity and status of the victims of those offenses, as well as the injury to the image of civil service and to relations in the workplace, justify the delivery of a deterring message.,206

This exclusively gender-neutral conclusion regarding the particular harm of sexual harassment in civil service was repeated in Israel v. Zaken, ${ }^{207}$ which involved a male state employee who sexually harassed a female colleague. In articulating the wrong of sexual harassment, the court concluded: "When the sexual harassment is exercised between state employees it harms the environment in the workplace, disrupts work relations, and even harms the proper function of the civil service and its appropriate image."208

These cases reveal that the relationship between gender inequality and sexual harassment has been completely excluded from the Israeli Supreme Court's contemporary legal discourse on sexual harassment. The court not only refrains from mentioning equality as a relevant value in this context, but the discriminatory harms of sexual harassment are clearly not part of the court's substantive understanding of this social practice, despite the systematic picture of subordination on the basis of gender that surfaces in each supreme court case reviewed here.

The problematic implications of this frame of analysis-which ignores the manner in which power differences and gender coincide in sexual harassment cases-are especially evident in recent supreme court cases that deal with

204. CSA 10088/02 Bazon v. Israel [2003] Tak-Al 2003(1) 1884.

205. Id. $\S 1$.

206. Id. $\S 5$.

207. CSA 6737/02 Israel v. Zaken [2002] IsrSC 57(2) 312.

208. Id. at 336 . 
situations of systematic harassment of several women in the same workplace. ${ }^{209}$ In Baruchin, when the court first faced a situation of systematic harassment along gender lines, the court reinforced the gender-neutral perspective and focused its discussion on the fact that several individual dignitary offenses were committed, rather than only one. ${ }^{210}$ In contrast, in some subsequent cases that discuss similar incidents of systematic harassment-especially those involving young women - the multiplicity of female victims has led the Israeli Supreme Court to intensify Galili's moralistic and paternalistic frame of reference. In Eisner, ${ }^{211}$ for instance, where a high school teacher sexually harassed at least six of his female students, Justice Beinish chose patriarchal language, rather than an equality-based analysis, to address the offense. Instead of connecting the facts of the case explicitly or implicitly to questions of gender equality in education, the court highlighted the special need to protect female school students from sexual conduct that is inappropriate for a dignified school teacher:

[S]exual conduct within a relationship between a male teacher and female students is perceived as much more severe than sexual harassment between workers in the workplace... . The public's trust in the educational system might be destroyed if a teacher who betrayed this trust remains in his job. . . One should hope that the appellant, who continues to work as a teacher, internalized the message that the disciplinary measures are designed to convey. . . and will be deterred in the future from any expression of an offending sexual nature and inappropriate conduct, in order to preserve and maintain in a dignified manner his status as a teacher. ${ }^{212}$

At the end of the day, Alon Eisner was condemned and punished for undermining public trust in the educational system and for breaking civility codes to which a school teacher should conform, especially in relation to female students. Questions about the basic rights of those female students were left out of the discussion.

The court's repeated emphasis on the sexual content of the harassment is another theme which has become more apparent in recent cases. This theme, which first appeared in Ben-Asher, has been taken to support the proposition that sexual harassment should be identified based on the apparent sexual motivation and desire of the harasser, in addition to the sexual content of the

209. See, e.g., CSA 1599/03 Tapiro v. Civil Serv. Comm'r [2003] IsrSC 58(2) 125; CSA 8431/01 Israel v. Danino [2001] IsrSC 56(2) 577; CSA 2868/04 Shamian v. Civil Serv. Comm'r [2004] Pador 04(8) 764; CSA 882/03 Ben-David v. Civil Serv. Comm'r [2003] Tak-Al 2003(2) 3276.

210. See supra notes $165-71$ and accompanying text.

211. CSA 1 1025/02, 65/03 Eisner v. Israel [2003] IsrSC 57(5) 541

212. Id. at 552. Eisner was convicted for three of the six alleged incidents of sexual harassment. Yet since those incidents were not defined as very severe, he was not removed from public service and was only transferred to another school and subjected to some additional disciplinary measures. 
behavior itself. ${ }^{213}$ In its efforts to identify prohibited forms of harassment, the court not only focuses on the "sexual" in sexual harassment, but also limits the scope of its inquiry to whether the harassment was driven by sexual motivation. As a result, other potentially relevant motivations triggering instances of sexual harassment, such as hostility towards women, are automatically excluded from the discussion. ${ }^{214}$ The case of Ben-David v. Civil Service Commissioner offers an extreme illustration of this line of analysis and of its detrimental consequences for women. ${ }^{215}$ Ben-David, a senior official in the Land Tax Department at the Ministry of Treasury, was accused of sexually harassing three women employees in his department. With regard to one incident, it was determined that his acts did not constitute sexual harassment. In this incident, Ben-David offered one of the complainants a lift home late at night at the end of an after work social event. On the way, he drove to the beach despite the complainant's protests. He stopped there for a few moments and finally took the complainant home. ${ }^{216}$ The disciplinary court acquitted Ben-David of this charge of sexual harassment, arguing that "the incident had no sexual connotation, and therefore even if the appellant's behavior was reprehensible on the personal level, it did not constitute a disciplinary offense [of sexual harassment]. ${ }^{, 217}$ The employee was denied relief solely because the alleged act of harassment and intimidation committed by her boss was not found by the court to have a sexual overtone and motivation. Similarly, regarding an incident in which Ben-David called another female subordinate "an idiot," shouted at her "get out of my sight," and threatened to throw a stapler at her, he was charged not with sexual harassment but with an offense of misconduct between civil servants, again because of the non-sexual nature of the alleged behavior. ${ }^{218}$ Where a certain act of harassment did not meet the double criteria of sexual content and sexual desire, the court automatically excluded it from the purview of the law, thereby avoiding any attempt to examine whether alternative parameters such as the gendered significance or consequences of the harassment could assist in defining those acts as gender-based harassment.

Hostile environment sexual harassment frequently has the aim or effect of denigrating the harassee's competence at work and it often has a clearly gendered connotation. Calling a female employee "an idiot," "dumb," or "stupid" perpetuates patriarchal stereotypes regarding women's low intellectual

213. See, e.g., CSA 882/03 Ben-David v. Civil Serv. Comm'r [2003] Tak-Al 2003(2) 3276; CSA 6920/03 Cohen v. Israel [2004] IsrSC 58(3) 655.

214. Vicki Schultz argues that many instances of sexual harassment are not driven by desire for sexual relations and are not even sexual in nature. Instead many forms of gender based harassment are driven by sheer hostility toward women and are designed to maintain the workplace as a masculine domain. For elaboration of this claim, see generally Schultz, supra note 129.

215. CSA 882/03 Ben-David v. Civil Serv. Comm'r [2003] Tak-Al 2003(2) 3276.

216. Id. $\S 1$.

217. Id. $\S 3$ (emphasis added)

218. Id. 
capacities and presents women as professionally incompetent. Therefore, if the sexual focus is abandoned and instead courts examine in every particular situation whether the conduct had "the purpose or effect of undermining the woman's right to participate in the workplace on an equal footing," ${ }^{219}$ new forms of gender-based harassment such as Ben-David's behaviors may come to light.

In a similar manner, the case of Dr. Abraham Cohen, ${ }^{220}$ who was in charge of research at the Ministry of Science and who repeatedly harassed his assistant (a Ph.D. student who was hired on a temporary basis), ${ }^{221}$ focused exclusively on his sexual intentions and the sexual nature of the behavior. The harasser claimed that all his sexual gestures were motivated by friendship and affection toward the complainant ${ }^{222}$ but the court rejected this claim. With regard to a particular event in which the harasser tried to kiss the complainant against her will, the court determined that "this event raises no doubt as to the real [sexual] intentions of the appellant and the true interpretation of his acts. ${ }^{223}$ On the other hand, with regard to a different incident in which, during a mutual train ride to a conference in Germany, the harasser touched the complainant's knee, the court determined that this touching was not sexually motivated and therefore decided to acquit the defendant on that count of the indictment. The court did not address the fact that, irrespective of his sexual desires, the harasser created a hostile working environment for the complainant, in which various forms of harassment tainted almost every professional interaction she had with her supervisor. ${ }^{224}$ All that was perceived relevant for the disciplinary conviction and for its approval by the supreme court was that certain incidents of harassment were sexual and sexually motivated.

Contemporary judicial discussion of sexual harassment excludes in advance the possibility of defining other expressions of hostility toward women as gender harassment, and leaves various forms of harassment with clear gendered characteristics beyond the reach of the law and its enforcement.

219. Schultz, supra note 129, at 1801-02.

220. CSA 6920/03 Cohen v. Israel [2004] IsrSC 58(3) 655.

221. Id. at 657 .

222. Id. at 659 .

223. Id. at 661 .

224. The defendant was convicted on three counts of the disciplinary indictment. According to the first count, he sexually harassed the complainant during many car rides they took together for professional purposes. During those rides he used to make comments to her such as "How beautiful you are" and "It is so pleasant to work with you" while touching and petting her arm. He did so despite the fact that the complainant told him several times she did not feel comfortable with his behavior. According to the second count of the indictment, when hosting a scientific delegation from Germany, the defendant invited her to his hotel room to freshen up before dinner. He promised not to enter the room while she was there, but broke his promise and tried to kiss her against her will. According to the third count, he tried to kiss her on her cheek during a ride to a professional meeting at one of the universities. 


\section{B. Sexual Harassment Caselaw in Lower Courts}

Paralleling the opinions of the supreme court that have interpreted the Prevention of Sexual Harassment Law and determined the parameters of its application, a broad and detailed body of opinions has been issued by the lower courts. In these opinions, which have accumulated in the course of criminal proceedings, disciplinary proceedings against state employees, proceedings in labor courts, and even in tort cases, we encounter four discursive themes similar to those found in the supreme court caselaw. Occasionally, lower courts quote the preamble to the law, which mentions the principle of equality as relevant to the discussion of sexual harassment, but substantially, the concept of dignity rules supreme in defining the significance and nature of the offense of sexual harassment. The dignitary paradigm of sexual harassment ranges from gender-neutral/individual analyses of sexual harassment to a definition that moralizes and stereotypes women. Finally, in adhering to the restricted 'sexual' definition of sexual harassment, lower courts identify and condemn sexual harassment only when it is a sexual behavior motivated by sexual desire.

For example, in Israel $v$. Rias, ${ }^{225}$ an executive manager of a factory harassed five women workers. Here, the magistrate court adopted the neutral/individual frame of analysis when referring to Rias's behavior: "[O]ffenses of this kind must be uprooted by means of a deterring and painful punishment, in order to demonstrate society's detestation of such acts, which harm the dignity of the other person's body and his/her freedom to choose with whom to make love."226

Likewise, in Tzabari, ${ }^{227}$ involving a senior manager in the publishing department of the Ministry of Defense who harassed four women employees under his authority, the appellate court upheld Tzabari's conviction and the punishment he received, stating:

The workplace is where a person spends a large portion of one's day and time. The person is entitled to do so in a neutral atmosphere, "free" of sexual connotations. The person must not be subjected to the views and preferences of another worker, who seeks to derive from an "atmosphere" of his/her own making opportunities for exploitation of the other and an offense against the other's values. ${ }^{228}$

Conversely, at the moralistic and stereotypical end of the spectrum are opinions such as that in the matter of Yitzhak Iluz, ${ }^{229}$ who served as adjutant in the Southern Command of the IDF and who sexually harassed several women soldiers under his command. When the Military Court of Appeals dealt with

225. CrimC (BS) 1451/01 Israel v. Rias [2001] Tak-Shal 2001(3) 52.

226. Id. (emphasis added).

227. CrimC (TA) 1034/00 Israel v. Tzabari [2003] (unreported case).

228. CrimA (TA) 71609/03 Tzabari v. Israel [2004] Pador 04(8) 282.

229. A 51/01 Iluz v. Gen. Military Prosecutor [2001] Pador 01(6) 100. 
this case, it resorted to the narrow and problematic connection between sex and women's honor:

We are weary of speaking about the severity with which it is imperative to regard the actions of commanders who exploit the status and authority they possess to make free with the bodies of women soldiers, be they NCOs or officers, in a way which offends the woman's dignity and constitutes a humiliating invasion of the individual's space. It is intolerable that commanders give free rein to their impulses by committing obscene acts against women serving in the $I D F^{230}$

The military court's decision in Iluz implicitly associated the indecent aspects of sexual behavior with its humiliating impact on women. As in Zarzar, ${ }^{231}$ the portrayal of the harasser as somebody who simply gave in to a human weakness reduced the significance of the harassment and disguised the elements of power and subordination involved. This not only perpetuated patriarchal notions regarding women's desired sexual purity, but also led to a very narrow and misleading understanding of the consequences of the pattern of harassment to which those women were subjected. The specific facts of the case indicate that Iluz was responsible for training the complainants and testing them in their work. He also served as their liaison with IDF headquarters, such that they could not perform their duties properly without his assistance, which he gave in exchange for sexual favors. ${ }^{232}$ The harassing behavior therefore undermined the women's professional status in the military. They were deprived of the opportunity to win professional respect and promotion on the basis of their skills and abilities, and their entire professional competence in the military was reduced to that of a sexual object. In the court's opinion, all these detrimental and clearly gender-based consequences were reduced to the single conclusion that what was essentially intolerable was the fact that Iluz committed humiliating "obscene acts" against those women.

Similarly, in Harush v. Israel, ${ }^{233}$ in which the Deputy Director of the Fund for the Promotion of Construction in Israel was convicted of sexually harassing one of his female secretaries, the appellate court stressed the "humiliation . . . caused by the appellant's behavior." ${ }^{234}$ The court further explained that "[p]recisely in light of the senior position of the appellant, he should have avoided giving free rein to his desires, and exploiting his position in the workplace in a manner that offended the complainant's honor." ${ }^{235}$ This judicial account of the harm of sexual harassment exclusively in terms of dignity and honor once again restricted the discussion to the indecency of the harasser and

230. Id. at *4 (emphasis added).

231. CSA 309/01 Zarzar v. Civil Serv. Comm'r [2001] IsrSC 55(2) 830.

232. A 51/01 lluz v. Gen. Military Prosecutor [2001] Pador 01(6) 100, at *1.

233. CrimA (TA) 70818/01 Harush v. Israel [2001] Tak-Mah 2001(4) 993.

234. Id. $\S 12$.

235. Id. (emphasis added). 
the humiliation of the victim, while disregarding the significance of the fact that the various incidents of harassment eventually caused the woman to quit her job. ${ }^{236}$ Here too, instead of a complex discussion of the link between the specific incidents of sexual harassment and the structural and discriminatory injury to the woman's position in the workplace, the judicial analysis trivialized the phenomenon and obscured some of its more detrimental consequences. Indeed, as lower courts deal with more cases of sexual harassment, sexual harassment is further trivialized and decontextualized in a manner that creates a widening gap between the specific, gendered realities that characterize each of those cases and the judicial analysis and understanding of those realities.

Amir Aharoni, for instance, served as a military policeman with the Border Control Unit, ${ }^{237}$ a predominately male unit that started to accommodate women in small numbers only recently. ${ }^{238}$ Aharoni was accused and convicted of sexually harassing all three women who served with him, constantly subjecting them to sexual remarks and propositions that created a hostile and demeaning working environment in the unit along clearly gendered lines. However, the court was extremely lenient with Aharoni. Employing the "moment of weakness" rhetoric that surfaced in previous cases, the court described the defendant as "a man who had a slip of the tongue against women who served with him."239 Furthermore, the court noted that the testimony of the complainants made clear that verbal sexual harassment was common practice in the unit. ${ }^{240}$ Hence, the fact that Aharoni's actions were part of, and a reflection of, a larger culture of sexual harassment was held in his favor. The court also referred to the solely verbal nature of the harassment, and to the fact the women whom Aharoni harassed were not subordinate to him but were his coworkers. The court regarded this too as a mitigating factor. The court also mentioned that the probation officer did not perceive Aharoni as a potential sex offender. ${ }^{241}$ What the court could have easily identified as a typical pattern of hostile environment sexual harassment of a small group of women in a traditionally male-dominated military unit was decontextualized once the broader gender hierarchies that characterized the situation were ignored. Neglecting to identify the role the harassing behaviors played in preserving the masculine image of that workplace and their relationship to the broader culture of harassment against women that prevailed in that unit, the case was then presented as an incidental matter of minor sexual misbehavior. The fact that Aharoni was not a

236. In this case, as in the supreme court case Levi, the appellate court did mention the fact that the harassed woman had to quit her job, but refrained from explaining the meaning of this fact in the context of the sexual harassment of working women and how and why it adds an important aspect to the analysis and understanding of harm in such cases. See supra notes 180-190.

237. CrimC (Hi) 5977/01 Israel v. Aharoni [2005] Pador 05(7) 782.

238. Id.

239. CrimC (Hi) 5977/01 Israel v. Aharoni [2005] Pador 05(23) 840, 844.

240. Id. at 843 .

241. Id. at $843-44$ 
recidivist sex offender and that he was convicted not of physical but merely of verbal harassment of those women - a practice that was widespread-justified abandoning the criminal conviction and replacing it with a civil obligation of community service. $^{242}$

The case of Josef Ben-Haim ${ }^{243}$ also dealt with incidents of sexual harassment in a male-dominated workplace. Ben-Haim, a senior police officer, was accused of sexually harassing a young woman who worked for a private security company that assisted the police in securing the area of the Western Wall in Jerusalem. The charge against Ben-Haim was that, during a night mission with the complainant, he constantly touched her body, hugged her, pinched her cheeks, and so on. ${ }^{244}$ The court fully believed the testimony of the complainant, and noted specifically:

The complainant, who started to work for the security company after she finished her military service, testified coherently and [successfully] faced a long and tortuous cross-examination. We are talking about a reliable and serious young woman with high moral values who was very upset by the [physical] contact the defendant initiated with her . ... In her testimony, she testified in great detail as to what happened that day, and it was apparent that the event caused her a lot of pain. ${ }^{245}$

However, the court acquitted the defendant, on the grounds that the complainant had not made it clear to the defendant that his behavior was unwelcome. In addition, it seemed more probable to the court that the complainant, who was perceived as an overly-sensitive young woman, had misattributed a sexual nature to the defendant's behavior toward her. ${ }^{246}$ Summarizing the broader conclusions to be drawn from the event, the court ended up justifying rather than condemning the exclusion of women from jobs traditionally held by men:

The mission that was exercised after midnight in a dark, quiet and mysterious area could cause any reasonable person, and especially a young woman, [to be in a state of] suspicion and distress .... I believe that using a young girl for such a mission in the late hours of the night is clearly wrong, and the security forces should reconsider [this policy] in the future. An exercise intended to assess the alertness of policemen can be performed in a different way and without [the presence of] a young woman who is not part of the police force. ${ }^{247}$

242. In certain criminal cases, the court has the discretion to mitigate the consequences of a conviction before the defendant is sentenced by abandoning the criminal aspect of the conviction. This prevents the creation of a criminal record for the defendant, and allows the court to impose a light punishment such as community service. In the case of Aharoni, he was ordered by the court to serve 600 hours of community service and to pay 2000 Israeli Shekels to each of the three complainants.

243. CrimC 4944/04 (Jer) Israel v. Ben-Chaim [2006] Pador 06(9) 687.

244. Id. at*1.

245. Id. at $* 8$.

246. Id. at *9.

247. Id. 
Unlike the other cases dealing with incidents of sexual harassment in maledominated settings such as the military and the police, Ben-Haim added a gendered perspective to the analysis. However, gender was integrated into the discussion as a repository for a moralistic and patriarchal perception of women. Concluding that the "real" problem in the case was the presence of young and sensitive women in places where they do not belong, the court suggested driving these women out of such non-traditional professional spheres, thereby promoting one of the most adverse effects of sexual harassment in a maledominated setting. ${ }^{248}$ Thus, the Ben-Haim court, in its efforts to provide proper protection for the specific female complainant, furthered her subordination beyond the original crime, and reinforced the idea that women cannot meet the demands of "a man's job."

An additional aspect of sexual harassment caselaw in the lower courts is the ongoing emphasis on the "sexual" nature of sexual harassment, an emphasis that completely ignores the full nature and various consequences of this social practice. Here too we witness a growing gap between reality and the judicial rhetoric analyzing and responding to this reality. Israel $v$. Fridenberg provides an interesting example in this context. ${ }^{249}$ This case involved an employer who habitually made crude sexual remarks to one of his female employees. In addition to these remarks, he subjected her to hostile comments of a non-sexual but gender-stereotypical nature, such as "dummy," "retarded," "thickie," and "you don't understand anything.", 250 After one incident in which he also slapped her, she filed a complaint with the police, and as a result she was fired. In this case, much like Ben-David, the court had an opportunity to promote a broader understanding of the complex nature of harassment that women are subjected to. It might have highlighted the distinction between "sex-based harassment" and "gender-based harassment,",251 and brought into question the prevailing judicial conclusion that "behavior will not be considered sexual harassment, even if it is harassing, if it is not of a sexual nature or is [not] expressed in matters associated with sex."252 However, no such discussion took place, and the case was characterized as another typical example in which the woman was simply subjected to "repeated suggestions of a sexual nature.",253

248. Feminist literature on sexual harassment argues that the sexual harassment of working women in predominantly masculine jobs serves as an effective tool for driving them out of those prestigious jobs. See MACKINNON, supra note 68, at 143-213.

249. CrimC 2334/02 Israel v. Fridenberg [2003] (unreported case).

250. Id.

251. Schultz, supra note 129 , at 1744 .

252. CSA 6713/96 Israel v. Ben-Asher [1998] IsrSC 52(1) 650, 654.

253. CrimC (RL) 2334/02 Israel v. Fridenberg [2003] (unreported case). 


\section{SeXual Harassment LaW: Between the Limits of LAW AND the LIMITS OF FEMINISM}

More than nine years after its enactment, the Prevention of Sexual Harassment Law has contributed to a higher degree of enforcement than existed under former sexual harassment legislation in Israel. It has created an easily implemented legal framework for prosecutors and judges, and has produced a substantial body of opinions that have not only imposed personal liability on persons charged with sexual harassment, but also stressed the importance of eradicating this social practice.

However, as shown in Part III of this Article, contemporary judicial conceptualization of sexual harassment and its harms, as confined to the boundaries of the dignitary paradigm that was integrated into the new legislation, has suffered from several defects. This paradigm created a line of demarcation between sexual harassment and sex discrimination, such that sexual harassment is no longer discussed in terms that associate it with gender inequality and highlight its discriminatory aspects. Rather, the exclusive focus on dignity has diverted the judicial discussion of sexual harassment to a few distinct rhetorical avenues that each hinder the battle against sexual harassment in a different manner.

This process, in which the courts have reconstructed the Prevention of Sexual Harassment Law in terms that are very distant from the original goals of its feminist proponents, appears to be the product of three crucial choices made by those who drafted the new legislation. The first was the decision to list gender equality as the last of several values that were declared relevant for the analysis of sexual harassment. The second decision, which immediately followed the first, was the decision to award a special and primary role to human dignity (or kavod) as the central normative frame of reference for the definition of the wrong of sexual harassment. These two choices led to the conscious drafting of section 1 of the law, which provides, "The objective of this Law is to prohibit sexual harassment, in order to protect human dignity, liberty and privacy and in order to promote equality between the sexes."254 The third crucial choice in this context was the decision to criminalize sexual harassment in a manner that associated it with other sex offenses such as indecent behavior.

The immediate implications of all those choices are evident in the judicial opinions that are discussed in Part III. While the feminist forces who promoted the new legislation clearly articulated their intentions regarding the proper interpretation of the law during the legislative deliberation, they provided the courts with a legal framework that was open to alternative interpretations. For instance, the decision to present gender equality as supplementary rather than 
as the sole defining value of the wrong of sexual harassment created a different dynamic than the drafters may have expected. While feminist actors were trying to promote a broad and diversified understanding of sexual harassment that preserved a close tie between dignity and equality, the courts simply replaced equality with dignity. Once presented with an assembly of values that all define the harm of sexual harassment, Israeli courts were no longer required to understand the possible nexus between sexual harassment and gender inequality. Contrary to American courts, which must struggle with the question of why sexual harassment constitutes gender discrimination, Israeli courts were offered an easier option: to link sexual harassment to a well-established value such as dignity (kavod) that also tied in with their common-sense understandings. Once kavod became the sole focus of court opinions dealing with sexual harassment, it turned out that there was more than one understanding of the dignitary harm of sexual harassment. The multiple meanings embedded in the term kavod opened the door to various interpretations of the dignitary paradigm of sexual harassment ranging from traditional and often patriarchal perceptions of women's honor to the more liberal yet highly individual and gender-neutral value of human dignity. This multiplicity of meanings inherent to the term kavod created a genuine normative ambiguity as to what constitutes sexual harassment.

Finally, the decision to criminalize sexual harassment in a manner that coupled all forms of sexual harassment with certain sex offenses such as "indecent behavior" also brought unexpected consequences. This linkage between sexual harassment and sex offenses signaled behavior of a sexual nature as an important feature of the new legislation, and provided implicit support for the Israeli Supreme Court's immediate focus on the "sexual" in sexual harassment. Furthermore, the association of sexual harassment with sexual behavior allowed a moralistic conceptualization to dominate the dignitary harm of harassment. Once sexual harassment was reduced to sex, and the dignity/honor paradigm of the law made it possible to divert the discussion of harm to women's honor, a moralistic conclusion regarding the manner in which sex offends women's honor could find support in the general framework of the law.

In addition, it is important to remember that criminal discourse focuses on questions of guilt at the individual level, since the very concept of personal guilt stands at the core of criminal liability, while equality is not a value that is usually promoted or defended through criminal law. These features of criminal law can explain the gender-neutral/individual conceptualization of sexual harassment that characterizes one of the court's themes of analysis. This theme, when exercised as part of the criminal discussion of guilt and harm, confines the discussion to the particular harasser and the individual humiliation of his or her victim and excludes as irrelevant questions relating to the broader gendered 
context that allows the harassing behavior and intensifies its harm. Aharoni, discussed above, illustrates this process and highlights its problematic implications. $^{255}$ Aharoni was not alone in verbally harassing the three policewomen in his male-dominated unit. Accordingly, the court determined that verbal sexual harassment was the common practice in the unit. But while this fact provided a clear example of the way in which women's full integration in traditionally segregated jobs is hindered through repeated patterns of sexual harassment, from the criminal perspective it was a mitigating factor with regard to the individual criminal liability of Aharoni himself. Ultimately, it contributed to the extremely light punishment-community service without a criminal record-that the court handed down.

Hence, the linkage between sexual harassment and some specific sex offenses undermined the development of sexual harassment caselaw in two important respects. It provided implicit support for the court's focus on the "sexual" in sexual harassment and its moralistic interpretation of the dignitary harm of this social practice as relating to women's honor, and it restricted the development of sexual harassment discourse within the special boundaries of criminal law.

It appears, then, that the judicial interpretation of sexual harassment law in Israel cannot be separated from the conscious choices made by those who drafted the law, including its feminist proponents. Moreover, this interpretive framework reflects a widening gap between the original rationale of the feminist groups that promoted the dignitary paradigm of the new legislation and the courts' subsequent interpretation and conceptualization of that paradigm. The courts neglected and eventually ignored the feminist proponents' original claim that sexual harassment mirrors and enhances discrimination against women and their subordinated status in society. Instead, judicial discourse on sexual harassment promotes a very limited and sometimes misleading understanding regarding the nature, causes, and implications of this practice, which impedes the struggle against sexual harassment in two distinctive ways.

The neutral/individual interpretation of the dignitary harm of sexual harassment silences questions and understandings regarding the gendered aspects of this social phenomenon. The prevailing rhetoric of gender neutrality hides the complex reality of gender hierarchy that underlies and facilitates many situations of sexual harassment. As this Article reveals, the vast majority of Israeli sexual harassment cases bear an unmistakably gendered significance. The harasser in all reported cases I have identified is a man, the target is almost always a woman (or several women in the same setting), and the predominant

255. CrimC (Hi) 5977/01 Israel v. Aharoni [2005] Pador 05(7) 782; see also supra notes 237-242 and accompanying text. 
context of the offense is power differences on clearly gendered lines. ${ }^{256}$ In this respect, Israeli sexual harassment cases reveal the reality of gender discrimination in the workplace, in education, and in the military, and serve as a powerful reminder that sexual harassment is a group-based social problem that involves clearly gendered harms.

Moreover, since the linkage between sexual harassment and gender inequality draws on the actual life experiences of many women (and a few men), experiences that are documented in hundreds of cases, the fact that Israeli courts ignore and even actively disguise this linkage has real consequences for women. By promoting a partial and at times false understanding of sexual harassment, contemporary judicial discourse undermines possible solutions to this problem. If sexual harassment is discussed and presented as the aberrant conduct of genderless individuals that harms some other genderless individuals with no group significance, a court ruling in a specific case involving incidents of harassment becomes the only possible legal response to the problem. In contrast, an alternative conclusion emerges if sexual harassment is understood as one expression of the lower status of women in general and in the workplace in particular, in the broader context of the unequal gender power relations that produce and enable sexual harassment. It then becomes clear that a judicial ruling in an individual case will never serve as an effective tool against sexual harassment if it is not accompanied by broader legal measures that are designed to promote greater gender equality, especially in the workplace. Thus, in its current state sexual harassment caselaw discourages further legal action against gender inequality in general and against sexual harassment in particular. In fact, this caselaw obscures the relationship between the two. Instead of becoming an educational, consciousness-raising tool that marks a new era in the awareness of sexual harassment and its distinct nature and harm among the Israeli public, the Prevention of Sexual Harassment Law has achieved the opposite, hindering the broader and more radical task it was envisioned to serve. By losing sight of sex discrimination, sexual harassment law no longer serves as an effective tool for changing society so that this social practice does not recur.

Additionally, the moralistic and patriarchal interpretation of the dignitary harm of sexual harassment hinders the battle against sexual harassment in a different and more devastating manner. This discourse stereotypes women in terms that are at odds with basic precepts of gender equality, thereby creating a body of caselaw that effectively undermines many of the rationales behind the feminist battle against sexual harassment. By reviving traditional, patriarchal concepts of women's honor, courts legitimate under the umbrella of feminist legislation concepts that are clearly anti-feminist. The Ben-Haim case, ${ }^{257}$ where

256. See supra note 116 and accompanying text.

257. CrimC (Jer) 4944/04 Israel v. Ben-Chaim [2006] Pador 06(9) 687; see supra notes 243-248 and accompanying text. 
the court, in its efforts to protect sensitive women from the harms of sexual behavior, eventually recommended sending them home, provides an extreme example of the possible implications of a rhetoric that places women's sensitivity and sexual purity, rather than their basic right to equality, at the center of the dignitary paradigm of sexual harassment law.

\section{CONCLUSION}

How do you turn an agenda of social change into a working legal practice? This question is at the core of the feminist struggle against sexual harassment. The dignitary paradigm of sexual harassment law represents an additional stage in this ongoing effort to recruit the law as an effective agent in combating and condemning a social phenomenon that is perceived as particularly harmful to women. However, the actual products of the Israeli Prevention of Sexual Harassment Law highlight the difficulties associated with using the law as an effective tool for social change.

Israeli sexual harassment legislation is the result of a carefully tailored and highly ambitious feminist initiative, which was designed to reconceptualize sexual harassment law in a manner that would make this legislation more effective in combating a problem that harms mostly women. In defending this initiative and especially in promoting a conceptual shift from an equality-based statute to a dignity-based statute, Israeli feminists emphasized several goals. The most challenging goal was the desire to correct some of the drawbacks of sexual harassment legal doctrine in the United States. Following the American example, Israeli feminists worried that the judicial notion of formal equality, which is intertwined with patriarchal ideology, might restrict the development of sexual harassment law in Israel as it did in the United States. They therefore suggested redefining sexual harassment as primarily a dignitary harm, hoping to cure the male-biased interpretation of equality by focusing the discussion of sexual harassment on a different value that appeared to them as less patriarchal. However, Israeli feminists did not fully grasp the broader implications of their own substantive critique regarding the patriarchal aspects of the judge-made concept of formal equality. While they argued critically that a male focus set the standard of equality in law, they did not further question their own decision to bolster equality with dignity as a proper solution to the problem. Following their own critique of the law, Israeli feminists could have wondered whether a formal shift from one legal value to another would relieve the law from its inherent gender entanglements. Those doubts should have been raisedespecially with regard to an ambiguous value such as dignity (or kavod) that embodies a number of meanings and concepts, some of them highly susceptible to traditional and patriarchal interpretations. In fact, the actual products of contemporary sexual harassment caselaw, which range from a genderless 
interpretation of sexual harassment to a stereotyping discourse on women and gender, suggest that the male bias is still deeply embedded in legal discourse and therefore similarly shapes the interpretation of the dignitary paradigm of sexual harassment.

In addition, Israeli feminists neglected to appreciate the significance of the fact that American courts have defined sexual harassment as a subset of employment discrimination. By categorizing behavior in particular terms and not others, laws provide a cognitive structure for understanding social behavior. By defining sexual harassment as sex-based discrimination, American courts have affirmed feminists' arguments that sexual harassment is a group-defined injury in employment. Even if the American courts did not fully comprehend MacKinnon's subordination argument, this legal categorization of sexual harassment privileged a gendered understanding of sexual harassment that is crucial in light of the actual characteristics of the social practice.

For Israeli feminists, then, as for all other advocates of the dignitary paradigm of sexual harassment, the Prevention of Sexual Harassment Law raises important questions regarding law's potential to serve as an effective bridge between radical agendas and existing social norms. 
